\title{
Does retirement affect cognitive functioning?
}

Citation for published version (APA):

Bonsang, E. D. M., Adam, S., \& Perelman, S. (2010). Does retirement affect cognitive functioning? METEOR, Maastricht University School of Business and Economics. METEOR Research Memorandum No. 5 https://doi.org/10.26481/umamet.2010005

Document status and date:

Published: 01/01/2010

DOI:

10.26481/umamet.2010005

Document Version:

Publisher's PDF, also known as Version of record

\section{Please check the document version of this publication:}

- A submitted manuscript is the version of the article upon submission and before peer-review. There can be important differences between the submitted version and the official published version of record.

People interested in the research are advised to contact the author for the final version of the publication, or visit the DOI to the publisher's website.

- The final author version and the galley proof are versions of the publication after peer review.

- The final published version features the final layout of the paper including the volume, issue and page numbers.

Link to publication

\footnotetext{
General rights rights.

- You may freely distribute the URL identifying the publication in the public portal. please follow below link for the End User Agreement:

www.umlib.nl/taverne-license

Take down policy

If you believe that this document breaches copyright please contact us at:

repository@maastrichtuniversity.nl

providing details and we will investigate your claim.
}

Copyright and moral rights for the publications made accessible in the public portal are retained by the authors and/or other copyright owners and it is a condition of accessing publications that users recognise and abide by the legal requirements associated with these

- Users may download and print one copy of any publication from the public portal for the purpose of private study or research.

- You may not further distribute the material or use it for any profit-making activity or commercial gain

If the publication is distributed under the terms of Article $25 \mathrm{fa}$ of the Dutch Copyright Act, indicated by the "Taverne" license above, 


\section{Maastricht University}

Eric Bonsang, Stéphane Adam, Sergio Perelman

Does Retirement Affect Cognitive Functioning?

$\mathrm{RM} / 10 / 005$

\section{METEOR}

Maastricht University School of Business and Economics

Maastricht Research School of Economics

of Technology and Organization

\section{PO. Box 616}

NL - 6200 MD Maastricht

The Netherlands 


\title{
Does Retirement Affect Cognitive Functioning? ${ }^{1}$
}

\author{
Eric Bonsang ${ }^{1,2}$, Stéphane Adam ${ }^{3,4}$, and Sergio Perelman ${ }^{2}$ \\ ${ }^{1}$ ROA, Maastricht University, ${ }^{2}$ CREPP, University of Liège \\ ${ }^{3}$ CPLU, University of Liège, ${ }^{4}$ Neuropsychology Unit, University of Liège.
}

\begin{abstract}
This paper analyzes the effect of retirement on cognitive functioning using two large scale surveys. On the one hand the HRS, a longitudinal survey among individuals aged 50+ living in the United States, allows us to control for individual heterogeneity and endogeneity of the retirement decision by using the eligibility age for Social Security as an instrument. On the other hand, a comparable international European survey, SHARE, allows us to identify the causal effect of retirement on cognitive functioning by using the cross-country differences in the age-pattern of retirement. The results highlight in both cases a significant negative, and quantitatively comparable, effect of retirement on cognitive functioning. Our results suggest that promoting labor force participation of older workers is not only desirable to insure the viability of retirement schemes, but it could also delay cognitive decline, and thus the occurrence of associated impairments at older age.
\end{abstract}

JEL Classifications: I12, J14, J24, J26

Keywords: aging, cognition, retirement, social security

\footnotetext{
${ }^{1}$ This paper uses data from SHARE release 2.2.0, as of August 19th 2009. SHARE data collection during 2004-2007 was primarily funded by the European Commission through its 5th and 6th framework programmes (project numbers QLK6-CT-2001-00360; RII-CT- 2006-062193; CIT5-CT-2005-028857). Additional funding by the US National Institute on Aging (grant numbers U01 AG09740-13S2; P01 AG005842; P01 AG08291; P30 AG12815; Y1-AG-4553-01; OGHA 04-064; R21 AG025169) as well as by various national sources is gratefully acknowledged (see http://www.share-project.org for a full list of funding institutions).
} 


\section{Introduction}

In most developed countries, the proportion of older individuals has substantially increased over the last decades. This demographic shift has increased the focus on health in aging. At the same time, increased life expectancy combined with a decline in average retirement age have increased the proportion of an individual's life spent in retirement. This structural change imposes many challenges for the financial sustainability of social security systems. Moreover, this extended retirement spell raises questions about its potential consequences on the physical and mental health of the elderly, which may in turn affect long-term care expenditures (Dave et al., 2008).

Older individuals face many challenges associated with physical and mental deterioration. Among these, the decline in cognitive capacity with age has been well documented: a large amount of evidence suggests that aging is associated with a decline in the ability to perform several cognitive tasks (Dixon et al., 2004; Schaie, 1994). More particularly, aging has a salient effect on episodic memory tasks ${ }^{2}$ (Petersen et al., 1992; Small, 2001), episodic memory deficits being also largely considered as a hallmark symptom of Alzheimer's disease (Adam et al., 2007; Dubois et al., 2007).

However, this decline is not homogenous across the population, with some people maintaining cognitive vitality even into extreme old age (Berkman et al., 1993; Silver et al., 1998; Silver et al., 2001). At the same time, age-related cerebral modifications that are at the root of Alzheimer's disease have been observed to have heterogeneous effects on cognitive functioning. For example, Katzman et al. (1989) described cases of cognitively normal elderly women who were discovered (by ways of post mortem analysis) to have advanced Alzheimer's disease pathology in their brains. Stern $(2002,2003)$ and Scarmeas and Stern (2003) propose the concept of cognitive reserve to explain this apparent absence of direct relationship between the severity of the factor that disrupts performance (such as the degree of brain modifications with age, or brain pathology associated with Alzheimer's disease) and the degree of disruption in performance or of dysfunction in daily life activities. This suggests that some individuals are able to more efficiently use their cognitive

\footnotetext{
${ }^{2}$ Episodic memory refers to memory of information about specific past events that involved the self (i.e. events personally lived) and occurred at a particular time and place (e.g., the last holidays).
} 
resources and thus are less susceptible to disruption. Individual heterogeneity may stem from innate or genetic differences, or different life experiences, such as occupational attainment or leisure activities.

The degree of resilience to these biological changes, i.e., the cognitive reserve, has been found to depend on several factors. Among these, education undoubtedly plays an important role (Evans et al., 1993; Le Carret et al., 2003). Moreover, differential susceptibility to age-related cognitive decline or to Alzheimer's disease has also been shown to be related to occupation (Evans et al., 1993; Letenneur et al., 1994; Schooler et al., 1999; Stern et al., 1994), professional or leisure activities (Carpuso et al., 2000; Scarmeas et al., 2001; Wilson et al., 2002; Newson and Kemps, 2005), and lifestyle (for a review, see: Fillit et al., 2002; and Fratiglioni et al., 2004).

In summary, this literature suggests that individual heterogeneity in the level of cognitive functioning and the rate of age-related change in cognitive functioning is associated with an individual's lifestyle, such as his engagement in mentally stimulating activities (Salthouse, 2006). This hypothesis is quite appealing, as it suggests that individuals have some control over the evolution of their cognitive functioning, and that there is scope for policy interventions to affect the pattern of cognitive aging.

However, the way the causality runs between activities and the brain remains an open issue in neuropsychology. Do activities improve cognitive functioning or are brighter people more often engaged in cognitively demanding activities? One argument favoring the first hypothesis can be found in the neurobiological literature, where several experimental studies on animals have shown that rats bred in an enriched environment present a greater dendritic density in the hippocampus and an increased number of glial cells than animals bred in standard conditions (Rosenzweig and Bennett, 1972). Moreover, Winocur (1998) showed that these brain modifications affect the cognitive abilities of older rats. A second argument in favor of the causal effect of activities on cognitive functioning can also be found in studies such as that of Maguire et al. (2000), which shows that taxi drivers in London, who had developed an intensive practice of orientation in the city, had significantly posterior hippocampi than control subjects, and above all, that the amount of occupational experience is correlated with the size of the hippocampus. Those studies show that stimulating activities and environment are able to improve, or maintain, cognitive functioning and that this has a direct effect on the brain. 
The aim of our study is to address the causal impact of lifestyle on cognitive functioning of older people by focusing on the relationship between cognitive functioning and retirement. Indeed, retirement implies major changes in individual lifestyle and is likely to affect involvement in activities that may contribute to maintaining, or improving, cognitive functioning at older age. If individuals have on average more cognitively stimulating activities at work than during retirement, we would expect a decline in cognitive functioning during retirement due to the decrease in stimulating activities, as suggested by the neuropsychological literature. From an economic point of view, cognitive functioning can be interpreted as a form of human capital, in particular health capital (Grossman, 1972), and its evolution will emerge from deliberate choices based on the perceived costs and benefits of investing in cognitive functioning. In the Grossman model, health capital is benefical as it reduces the time lost due to illness or injury, and thereby increases the time available to allocate to work, leisure, and health investments. The same reasoning may apply to cognitive functioning. Individuals with higher cognitive functioning may be more efficient in performing leisure and work activities, resulting in more effective time available to allocate to market and non-market activities. Eligibility for social security benefits corresponds to a drop in the relative wage rate in the Grossman model. It thus affects the marginal benefits and costs of effective time, and thus the investment in cognitive functioning. The marginal benefit is unambiguously lower, while the marginal cost may increase or decrease. This will depend on the relative marginal productivity of leisure and work. Due to social security benefits, work, as an investment in cognitive functioning, is more expensive. On the other hand, it decreases the cost of leisure, which also constitutes an input for cognitive functioning. The net impact of retirement on cognitive functioning can be positive, negative, or null. If the marginal productivity of work activities is always higher than the marginal productivity of leisure time, the eligibility for social security benefits will induce a decrease in cognitive functioning. In the case where labor has a low productivity and high non-labor productivity, the drop in the marginal cost may offset the decrease in marginal benefits and results in an increase in cognitive functioning when social security benefits become available.

In a recent study, Adam et al. (2007) found that retirees attain lower cognitive functioning than working individuals, using cross-sectional data from the United States and 
Europe. ${ }^{3}$ Furthermore, they show that the longer the retirement spell, the lower the cognitive score, which suggests an acceleration of cognitive decline during retirement. However, the difference observed across workers and retirees may have explanations other than a causal effect between retirement and cognition. First, impairments in cognitive functioning may prevent people from working, may increase disutility from work, or may lower productivity. Moreover, unobservable factors associated with cognitive functioning and retirement may be interrelated with both. Individuals with higher innate ability (and thus cognitive functioning) may invest more in human capital and retire at a later age than individuals with low innate ability.

Inspired by the research of Adam et al (2007), Coe and Zamarro (2008) and Rohwedder and Willis (2010) have also investigated the relationship between retirement and cognitive functioning by using cross-national data, the Survey of Health, Ageing, and Retirement in Europe (SHARE), and the difference in the legal age of retirement across countries as an instrument for retirement decision to avoid potential endogeneity bias. The results are mixed: while Rohwedder and Willis (2010) find a significant and quantitatively important (close to $40 \%$ ) negative effect of retirement on cognitive functioning, Coe and Zamarro (2008) do not find a significant effect.

In this paper we estimate the causal impact of retirement on cognitive functioning using data from two large scale surveys and using novel identification strategies. First, we use panel data from the HRS, a longitudinal survey among individuals aged 50+ living in the United States, that allows us to control for individual heterogeneity and to circumvent the issue of endogenous retirement decision by using the eligibility age for Social Security as an instrument. Our identification approach follows that of Bound and Waidmann (2007), Charles (2002), and Neumann (2008), who analyze the effect of retirement on health. As a robustness check, we use workers' subjective beliefs about their retirement dates as an alternative instrumental variable for retirement. Second, we use cross-country data from SHARE, but unlike Coe and Zamarro (2008) and Rohwedder and Willis (2010) we identify the causal effect of retirement on cognitive functioning by using the cross-country

\footnotetext{
${ }^{3}$ The Health and Retirement Study 2004 (United States); the English Longitudinal Study on Ageing 2004 (United Kingdom); the Survey of Health, Ageing, and Retirement in Europe 2004 (Austria, Belgium, Denmark, France, Germany, Greece, Italy, the Netherlands, Spain, and Sweden).
} 
differences in the age-pattern of retirement. The reason for that is that in European countries retirement eligibility depends not only on main Social security pension rules but also on eligibility rules, age is one among them, fixed by other social protection schemes, e.g. oldage unemployment, disability insurance, or early retirement schemes, in combination with labor market conditions (Gruber and Wise, 2004). The identification strategy will rely on the differences in the retirement age-patterns across countries and gender. Our results highlight in both cases a significant negative, and quantitatively comparable, effect of retirement on cognitive functioning, close to $10 \%$.

The paper is organized as follows. Section 2 describes the econometric approach used to address the empirical issues and Section 3 presents the data, the measure of cognitive functioning, and the explanatory variables included in the empirical model. Section 4 details the results from the longitudinal analysis using HRS and the results from the cross-national analysis using SHARE. Finally, Section 5 concludes and draws out implications from the analysis.

\section{Empirical model}

The aim of the empirical analysis is to test the hypothesis that retirement affects cognitive functioning. In our model, we assume cognitive functioning $\left(c_{i t}\right)$, measured by the score obtained at a cognitive test (described below), depends on retirement status $\left(r_{i t}\right)$, along with a vector of exogenous variables $\left(x_{i t}\right)$ including age, socio-demographic and health characteristics, and an unobserved error term $\left(\varepsilon_{i t}\right)$ :

$$
c_{i t}=f\left(x_{i t}, r_{i t}, \varepsilon_{i t}\right) \text {. }
$$

The error term can be decomposed into time-invariant individual heterogeneity $\left(\mu_{i}\right)$ and an idiosyncratic error term $\left(v_{i t}\right)$ :

$\varepsilon_{i t}=\mu_{i}+v_{i t}$.

Identification of the causal effect of retirement on cognitive functioning requires the error term and the retirement decision to be uncorrelated: $E\left(r_{i t} \varepsilon_{i t} \mid x_{i t}\right)=0$. This condition is unlikely to hold: first, retirement and cognitive functioning may be endogenous; low cognitive functioning may induce retirement. Second, unobserved individual heterogeneity may be correlated with both the retirement decision and cognitive functioning. Assuming 
linear separability, cognitive functioning and retirement are given by the following system of equations

$$
\begin{aligned}
& c_{i t}=x_{i t} \beta_{1}+r_{i t} \beta_{2}+\mu_{i}+v_{i t}, \\
& r_{i t}=x_{i t} \gamma_{1}+c_{i t} \gamma_{2}+w_{i t} \gamma_{3}+\omega_{i}+\eta_{i t},
\end{aligned}
$$

where equation (4) is the reduced-form equation of retirement decision, $w_{i t}$ is a vector of variables directly related to the retirement decision, but is assumed to have no direct effect on cognitive functioning, $E\left(w_{i t} v_{i t} \mid x_{i t}\right)=0$, and $\eta_{i t}$ is the idiosyncratic disturbance associated with retirement. From (3) and (4), the reduced-form model describing retirement decision is written as follows:

$$
\begin{aligned}
& r_{i t}=\frac{\gamma_{1}+\gamma_{2} \beta_{1}}{1-\beta_{2} \gamma_{2}} x_{i t}+\frac{\gamma_{3}}{1-\beta_{2} \gamma_{2}} w_{i t}+\frac{\gamma_{2}}{1-\beta_{2} \gamma_{2}}\left(\mu_{i}+v_{i t}\right)+\frac{1}{1-\beta_{2} \gamma_{2}}\left(\omega_{i}+\eta_{i t}\right), \\
& r_{i t}=\Pi_{1} x_{i t}+\Pi_{2} w_{i t}+\Pi_{3}\left(\mu_{i}+v_{i t}\right)+\Pi_{4}\left(\omega_{i}+\eta_{i t}\right),
\end{aligned}
$$

where $\Pi_{j}$ represents the reduced-form parameters. If the retirement decision depends on cognitive functioning $\left(\gamma_{2} \neq 0\right)$, retirement will be correlated with the error term $\left(\varepsilon_{i t}\right)$ in equation (1) through $\mu_{i}$ and $v_{i t}$. Moreover, retirement and the error term $\left(\varepsilon_{i t}\right)$ in equation (1) are likely to be correlated if the unobserved fixed individual heterogeneity from retirement decision and cognitive functioning are correlated $\left(E\left(\mu_{i} \omega_{i} \mid x_{i t}\right) \neq 0\right)$.

The fixed effects (FE) estimator allows measurement of the parameters of interest, controlling for unobserved individual heterogeneity. The effect of retirement on cognitive functioning $\left(\beta_{2}\right)$ will be consistently estimated unless $v_{i t}$ is correlated to the retirement decision (i.e. $\gamma_{2} \neq 0$ ). Moreover, the FE estimates are also susceptible to attenuation bias from measurement error in the retirement variable (Griliches and Hausman, 1986). We deal with those issues by using Instrumental Variable (IV) methods. The instruments correspond to the vector $w_{i t}$ in equation (4). To be valid instruments, the variables in the vector $w_{i t}$ must be related to retirement decision $\left(\gamma_{3} \neq 0\right)$ and correlated to cognitive functioning only through the effect of retirement $\left(E\left(w_{i t} v_{i t} \mid x_{i t}, \mu_{i}\right)=0\right)$. Large spikes in the retirement hazard at ages 62 and 65 have been well noted in the literature, and Social Security has been found to play a significant role in explaining such spikes (Burtless and Moffit, 1984; Gruber and Wise, 1999; Coile and Gruber, 2000). We thus use these key retirement ages in the United States as identifying instruments for the retirement decision. Age 62 represents the earliest 
age at which Social Security benefits can be claimed, while age 65 is the normal age of retirement in the US. Note that the normal retirement age is set to increase to age 67 over a 22-year period; this affects people born January 2, 1938, and later. ${ }^{4}$ We thus compute two dummy variables equal to 1 if the individual belongs to the corresponding age-interval in the retirement equation, while the cognitive functioning equation includes age as a smooth function using low-order polynomials. While these specific age values are likely to have a direct effect on the decision to retire, it is less likely that they have a particular effect on cognitive functioning. The empirical strategy consists of estimating Equation (3) using the two-stage least-squares within estimator, with these age threshold dummies as instruments for retirement. As a robustness check, we also estimate the model by using an alternative instrument for retirement that corresponds to a dummy that is equal to one when the individual has reached her/his expected age of retirement.

The second part of the empirical analysis will use the cross-national difference in the pattern of retirement across European countries, which are mainly due to differences in institutional settings across countries, in order to identify the causal effect of retirement on cognitive functioning. We argue that the difference in the aggregate retirement profile across countries cannot be explained by differences in the profile of cognitive decline and can thus be used as an instrument for retirement decision.

\section{Data}

\subsection{The Health and Retirement Study}

The empirical analysis uses five waves (1998-2006) from the Health and Retirement Study (HRS). ${ }^{5}$ The HRS has been following a sample of Americans born between 1931 and 1941 and their partners since 1992. Since 1998, this survey has also included respondents from the Asset and Health Dynamics Among the Oldest Old (AHEAD) study (cohorts born between 1890 and 1923), and a representative sample of individuals born between 1924 and

\footnotetext{
${ }^{4}$ Table A1 in the Appendix shows the normal age of retirement for the different cohorts that we use for our empirical analysis.

5 The HRS is sponsored by the National Institute of Aging (grant number NIA U01AG009740) and is conducted by the University of Michigan.
} 
1930 (the Children of the Depression Age) and between 1942 and 1947 (War Babies). An additional sample of individuals born between 1948 and 1953 (Early Baby Boomers) was added in 2004. Most interviews were done by telephone, although exceptions are made when the individual has health limitations or when the household has no telephone. The data contain a wide range of information about mental and physical health, labor status, financial situation, the family, and activities of the respondents.

In our study, we restrict the sample to respondents aged between 50 and 75 . Moreover, all individuals are dropped from the study who report returning to work during the sampling period. This selection helps to temper measurement error issues in the FE models for the retirement variable. Finally, all observations are dropped where there are missing or unreliable values for the variables included in the model. The final sample includes 53,596 observations for 16,878 individuals.

\subsection{The Survey of Health, Ageing and Retirement in Europe}

The cross-national analysis uses data from the Survey of Health, Ageing and Retirement in Europe (SHARE). SHARE is a European multi-disciplinary survey including more than 30,000 persons born in or before 1954, and coming from 14 European countries ranging

from Scandinavia to the Mediterranean. ${ }^{6}$ In this paper, we use release 2 of the first two waves of the survey, which were conducted in 2004 and 2006. The data were collected using a computer assisted personal interviewing (CAPI) program, supplemented by a selfcompletion paper and pencil questionnaire. For more details on the sampling procedure, questionnaire content and fieldwork methodology, we refer readers to Börsch-Supan and Jürges (2005) ${ }^{7}$

We restrict the sample to respondents aged between 50 and 65 years because it is during this age window that there are important differences in the employment rate across countries. All observations where there are missing or unreliable values for the variables

\footnotetext{
${ }^{6}$ SHARE data includes fourteen European countries: Austria, Belgium, Czech Republic, Germany, Denmark, France, Greece, Ireland, Italy, the Netherlands, Poland, Spain, Sweden, and Switzerland.

${ }^{7}$ More information can be found on the SHARE website: http://www.share-project.org/.
} 
included in the model are discarded from the analysis. The final sample includes 32,641 observations.

\subsection{The measure of cognitive functioning}

The HRS contains measures of cognitive functioning based on simple tests. The empirical analysis using the HRS focuses on one key cognitive domain: episodic memory, which is assessed through a test of verbal learning and recall. The motivation for analyzing this particular cognitive domain is twofold: first, this cognitive aspect is particularly affected by aging; some studies even argue that this cognitive function is among the first to decline with aging (Souchay et al., 2000; Anderson and Craik, 2000; Prull et al., 2000). Second, the related measure used to assess episodic memory, i.e., the score obtained in a test of word learning and recall, does not suffer from floor or ceiling effects (excess of maximum or minimum values), which thus provides a more sensitive measure than other measures of cognitive functioning that only allow for limited variability in scores. In the HRS, the episodic memory task consists of learning a list of ten common words. ${ }^{8}$ The interviewer reads a list of 10 words (e.g., book, child, hotel, etc.) to the respondent, and asks the respondent to recall as many words as possible from the list in any order. Then, immediate and delayed recall phases are carried out. Immediate recall follows directly, while a short interval is inserted before the delayed recall. Memory score for this task is calculated by the sum of the number of target words recalled at the immediate recall phase and the number of target words recalled at the delayed recall phase (score ranging from 0 to 20). The memory score has a distribution close to the normal distribution with a sample mean of 10.5 and a standard deviation of 3.4 .

In the SHARE data, cognitive functioning is measured using a similar test of verbal learning and recall of ten common words, as for the HRS. The sample mean is 9.4 with a

\footnotetext{
${ }^{8}$ Note that the HRS in fact uses four different lists of common words and that respondents are asked a different list of words from the lists that they, and their spouse, had to answer during the previous wave. This is done in order to avoid the respondent remembering the words from that previous list. There is, in fact, evidence of such a learning effect with the first two waves of the HRS, where individuals were asked the same list of words.
} 
standard deviation of 3.3. Figure $1 \mathrm{a}$ and $1 \mathrm{~b}$ display the distirbution of the memory score for HRS and SHARE, respectively.

[Figure 1a and Figure $1 \mathrm{~b}$ about here]

Moreover, SHARE data also include a word fluency test score based on the task of naming as many animals as possible in 60 seconds. This task is aimed at measuring the executive functioning of the individual. The fluency score has a sample mean of 20.5 with standard deviation of 7.2.

To ease the interpretation of our results, we use standardized measures of the test scores as dependent variable in our analysis.

\subsection{The retirement variable}

There are many definitions of retirement. For the purpose of our analysis, we follow Lazear (1986) and define an individual as being retired if he is definitively out of the labor force with the intention of staying out permanently. In the model assuming exogeneity of retirement (i.e., without using IV techniques), we use a categorical variable describing retirement status and time spent in retirement for retired individuals. Retirement duration is measured using information about the month and year of interview and the month and year when the individual left his/her last job. The reference categories include "Working", "Retired for 0 to 4 years", "Retired for 5 to 9 years", and "Retired for 10 years or more".

For the model using IV methods with eligibility rules as instruments, we use a dummy variable related to retirement status: an individual is defined as "Working" if he claims to be currently working for pay and "Retired" if he reports not working. The analysis using SHARE data uses the same definition.

\subsection{The explanatory variables}

In addition to the retirement variable, we include several other explanatory variables that are likely to be related to cognitive functioning. The effect of education is measured using a second-order polynomial of years of education. ${ }^{9}$ Second-order polynomials of age are

\footnotetext{
${ }^{9}$ Note that this variable is truncated at 17 years of education in the HRS.
} 
included in order to account for the "normal" cognitive aging process. The effect of age is assumed to be quadratic, allowing cognitive functioning to decline at an increasing rate with aging. We control for health by including a variable equal to 1 if a doctor has ever told the respondent that he has had a stroke (or a transient ischemic attack), a heart related disease ${ }^{10}$, or high blood pressure. Finally, we include a dummy variable for single-living households, and a categorical variable for ethnicity (White/Caucasian, Black/African American, or Other) for HRS data. The cross-national analysis using SHARE includes a dummy variable equal to one if the individual is interviewed for the second time to account for the test-retest effect (contrary to the HRS, the list of words used for the word recall test is the same for both waves; it is thus possible that individuals who do the test for the second time attain a better score than those doing the test for the first time).

\section{Results}

\subsection{Evidence from the United States}

\subsubsection{Baseline results}

Column (i) of Table 1 presents the parameters of Equation (3) estimated by Ordinary Least Squares (OLS). ${ }^{11}$ Almost all coefficients are highly significant. These results are in accordance with the results obtained by Adam et al. (2007), who use data from Europe (SHARE and ELSA) and the United States (HRS). The coefficients on education and age have the expected signs and are highly significant.

Education is positively related to cognitive functioning, while age has a negative effect. Living in a single household may have two opposite effects on cognitive functioning. First, it may induce lower cognitive functioning due to the lack of social interaction (Ybarra et al., 2008). Second, it may stimulate cognitive functioning, as single-living individuals must deal alone with all tasks associated with management of the household. The empirical

\footnotetext{
${ }^{10}$ Heart-related diseases include heart attack, coronary heart disease, angina, congestive heart failure, and other heart problems.

11 The standard errors of the estimates are corrected for autocorrelation among the observations corresponding to the same individuals over time.
} 
results show that individuals living alone have a lower cognitive score. Consistent with the findings of Patel et al. (2002), suffering from a stroke has a large and significant negative impact on the dependent variable. The coefficients of the other health-related variables, i.e. having high blood pressure or a heart-related disease, are also negative and significant. All the coefficients related to retirement spell are negative and highly significant.

[Table 1 about here]

\subsubsection{The within estimator}

The OLS estimator does not take into account the unobserved individual heterogeneity that might be correlated to the explanatory variables in the equation, and it thus may lead to inconsistent estimates of the effects of the covariates on cognitive functioning. Column (ii) of Table 1 displays the parameters of Equation (3) estimated with the fixed effects model.

The effect of aging is more pronounced when we control for individual heterogeneity. This suggests that older individuals have unobserved characteristics that are positively related to their cognitive functioning. This may be due to cohort effects or a selection process where individuals with higher endowment in health, and cognitive ability, live longer than individuals with lower endowments. ${ }^{12}$ Regarding the health related variables, only the coefficients related to stroke and to heart-related disease remain negative and highly significant.

The parameters associated with retirement and retirement spell remain negative and highly significant, but their magnitude is lower as compared to the OLS estimates. This is what we can expect from the within estimator, as this controls for individual heterogeneity, which is likely to be negatively correlated to retirement. Moreover, the within estimator is more prone to attenuation bias due to measurement error in the retirement variable (Griliches and Hausman, 1986).

\footnotetext{
12 This result might also be due to attrition where individuals with lower cognitive performance are more likely to leave the panel.
} 


\subsubsection{The IV estimator}

The previous section showed that the negative effect of retirement on cognitive score remains, even when individual heterogeneity is controlled for. However, the transitory shocks in cognitive functioning may induce older workers to leave the labor force. Moreover, the within estimator exacerbates measurement error and is likely to suffer from attenuation bias. To solve those potential issues, we employ IV methods, using the eligibility rules as instruments for retirement in the same spirit of Bound and Waidmann (2007), Charles (2002), and Neumann (2008). We use age-threshold dummy variables for reaching the minimum age for being eligible for Social Security benefits (62 years) and the normal age of retirement as defined in Table A1 in the Appendix, as instruments for retirement. While these specific age values are likely to have a direct effect on the decision to retire, it is unlikely that they have a particular effect on cognitive functioning. The IV estimator uses only work/retirement status as an endogenous variable and thus does not take into account retirement duration. Table 2 presents the parameter estimates of the model estimated by the two-stage least-squares within estimator. ${ }^{13}$

The parameters of the first-stage equation describing the retirement decision are displayed in column (i). The instruments, i.e., the eligibility ages for Social Security, have large and highly significant effects on the probability of retirement. The probability of retirement increases by nine percentage points at age 62. The F-test of joint significance of the instruments proposed by Bound et al. (1995) confirms that they are significant predictors of retirement $(F(2,36710)=250.75)$. The Sargan-Hansen test of overidentifying restrictions does not reject the hypothesis that our instruments are valid.

The effect of retirement on memory score is negative and significant. It suggests that individuals retiring experience a drop in cognitive score by about 0.3 of a standard deviation ( $95 \%$ confidence interval -.56 to -.05 ). It corresponds to about one word less, or a $10 \%$ decrease in cognitive score. The estimate is larger than in the model that assumes exogeneity of retirement (See column (ii)), possibly due to measurement errors in the retirement variables that are likely to bias downward the within estimates. The Durbin-Wu-

${ }^{13}$ Table $2 \mathrm{~A}$ in Appendix presents the results of the two-stage least-squares estimator that does not control for unobserved time invariant heterogeneity. Those results are consistent with those presented in Table 2. 
Hausman test rejects the null hypothesis of exogeneity of retirement. This result suggests that the endogeneity bias, if any, tends to underestimate the impact of retirement on cognitive score. Nevertheless, these results reinforce our previous findings showing the negative relationship between retirement and cognitive functioning.

[Table 2 about here]

\subsubsection{Alternative instruments: expected age of retirement}

This section presents results of the IV model using an alternative instrument for retirement: expected age of retirement. This measure has been found to be a good predictor of actual date of retirement (Bernheim, 1989; Disney and Tanner, 1999). The HRS includes questions on whether and when the respondent plans to retire, and if there is currently no planned retirement date, when he thinks he will stop work or retire. ${ }^{14}$ For this purpose, we select all individuals who are working at the first interview year and who have reported the year they expect to retire. The instrument is defined as a dummy variable equal to 1 when the respondent has reached her/his expected retirement age. Table 3 displays the results of the model estimated by two-stage least-squares within estimator. ${ }^{15}$ The first stage equation shows that this instrument has a large and significant impact on the retirement decision. The probability of retirement increases by about 19 percentage points when individuals reach their expected retirement age. The F-test on the instrument shows that it has strong predictive power on actual retirement $(F(1,16190)=690.85)$. The estimated effect of retirement on memory score is again negative and significant and close to the previous within-IV estimator. The magnitude of the effect is estimated to be -0.24 of a standard deviation of the memory score (95\% confidence interval -0.43 to -0.06$)$.

[Table 3 about here]

\footnotetext{
${ }^{14}$ We use the measure available in the RAND HRS Data File (See Saint Clair et al., 2007).

${ }^{15}$ Table 3A in Appendix presents the results of the two-stage least-squares estimator that does not control for unobserved time invariant heterogeneity. Those results are consistent with those presented in Table 3.
} 


\subsubsection{Does cognitive functioning affect retirement expectations?}

Further evidence that causality runs from retirement to cognitive functioning comes from an analysis of the effect of cognitive functioning on retirement expectations. We estimate a model of retirement decision that includes cognitive score as an explanatory variable to check whether a drop in cognitive capacity may affect the propensity to work of older workers. For this purpose, we estimate Equation (4) and test the hypothesis that the coefficient of cognitive functioning $\left(\gamma_{2}\right)$ is equal to zero. To avoid the issue of simultaneity, we use retirement expectations of older workers as a proxy for labor force attachment, rather than actual labor force status. Our test analyzes whether cognitive functioning affects expectation of retirement at age 65. The validity of subjective expectation measures has been shown to provide strong predictive power of actual behavior (Manski, 2004; Disney and Tanner, 1999; Benitez-Silva and Dwyer, 2005). This proxy for labor force attachment allows measurement of the effect of a change in cognitive functioning on retirement expectations of older individuals, while avoiding the issue of simultaneity of cognitive functioning and labor force status. Table 4 presents the results of the fixed effects model on workers less than 65 years old. The coefficient of memory score is not significant, suggesting that changes in cognitive functioning do not affect the retirement expectations of older workers. These results are in accordance with Haardt (2008), who found no evidence that changes in cognition affect retirement decision, using the English Longitudinal Survey on Ageing (ELSA). These findings support our previous results that the negative relationship between cognitive functioning and retirement is unlikely to be due to reverse causality.

[Table 4 about here]

\subsection{Evidence based on cross-country comparisons}

In this section, we provide further evidence on the relationship between retirement and cognitive functioning from an international perspective. Gruber and Wise $(1999,2004)$ have highlighted the strong relationship between financial disincentives to work and the participation rate of older individuals across countries. As a result, a suitable instrument for retirement to analyze the causal effect of retirement on cognitive functioning would be the differences in financial incentives that older workers face across countries. However, those 
incentives are quite difficult to calculate in practice due to the complexity and the multitude of social security programs that exist across European countries. ${ }^{16}$ Contrary to the United States, where the major pathway to retirement is Social Security, many European countries have different pathways to retirement, including old-age unemployment, disability, early retirement schemes, and of course, legal retirement schemes.

Since our data set lack information that allows us to correctly calculate financial incentives for retirement (e.g. due to the absence of information on life-cycle contributions to retirement schemes), we use the differences in the aggregate employment rate by country, gender and age, which capture financial incentives and institutional rules, but are unlikely to be caused by differences in cognitive decline across countries. The heterogeneity in the ageprofile of retirement across countries can thus be used as an instrument to analyze the causal effect of retirement on cognitive functioning.

The micro-analysis includes the same controls as for the empirical analysis on HRS data: a second-order polynomial in age, gender, country dummies, years of education ${ }^{17}$, three dummies equal to 1 if a doctor has ever told the respondent that he has had a stroke (or a transient ischemic attack), a heart related disease, or high blood pressure.

\subsubsection{Country-level analysis}

Adam et al. (2007) found a relationship between the differences in cognitive scores between 50-54 and 60-64 year-old men relative to the score of the 50-54 year-old men across European countries and the US. They found that the relative decrease in cognitive score was higher in countries where the drop in employment was also higher. Figure 4 replicates the figure of Adam et al. (2007) with the updated data of SHARE using the pooled sample from the two first waves and HRS 2004 where cognitive functioning is measured by the word recall test, while Figure $4 \mathrm{~b}$ uses the fluency score as a measure of cognitive functioning (and thus where the United States is lacking). As in Adam et al. (2007), these figures highlight a strong relationship between the relative decrease in cognitive score and the

16 Other than the complexity of computations, the main limitation is unavailability of complete data on professional life, to perform retirement incentives' computations.

17 Years of education are constructed for the different SHARE-participating countries according to the 1997 International Standard Classification of Education (OECD, 1999). 
relative decrease in employment rate across those two age categories. If we compare those figures with Figure 3 from Gruber and Wise (1999), which highlight the strong relationship between the tax force to retire and the unused labor force capacity among older workers, we see that the greatest drops in the employment rate occur in countries where financial disincentives to work are the highest. The coefficient of the regression line fitting the relationship between the relative drop in employment rate and the relative drop in cognitive functioning suggests that retirement decreases cognitive functioning by about $10 \%$. This result is consistent with those obtained by the individual-level analysis that uses the longitudinal dimension of the HRS and the eligibility age for Social Security, or the expected age of retirement, as an instrument for retirement.

[Figure 2, Figure $3 \mathrm{a}$ and Figure $4 \mathrm{~b}$ about here]

\subsubsection{Individual-level analysis}

SHARE also allows the estimation of the causal effect of retirement on cognitive functioning at the individual level. We use the aggregate employment rate by country, gender and age as an instrument for retirement to estimate the causal effect of retirement on cognitive functioning. The aggregate employment rates are directly calculated from SHARE data as the average employment rate by country, gender and age. ${ }^{18}$ This measure is then used as an instrument for individual retirement.

[Table 5 about here]

Table 5 presents the results of the OLS and the IV model using the normalized fluency score and the normalized word recall test score as the dependent variable. ${ }^{19}$ The results for both cognitive tests are very similar, especially regarding the retirement status. Moreover, the effect of being retired on cognitive score estimated by OLS is also similar to the OLS estimates obtained using the HRS data. By construction, the instrument in the first-stage

\footnotetext{
${ }^{18}$ As a robustness check, we also calculated those aggregate employment rates by using data from the Labour Force Survey and obtained the same results.

19 Table 4A in Appendix presents the results of the estimations made on the sample including both SHARE and HRS data (from 2004). Results do not differ significantly from those presented in Table 5.
} 
equation is highly significant. The IV estimates of the effect of being retired on both cognitive scores are also very similar and close to the results using the HRS data. The magnitude of the effect is estimated to be -0.2 of a standard deviation of the memory score ( $95 \%$ confidence interval -0.28 to -0.09 ) and -0.18 of a standard deviation of the fluency score $(95 \%$ confidence interval -0.28 to -0.09$)$. As for the model using longitudinal data from the HRS, the IV estimator confirms the negative effect of retirement on cognitive functioning for both cognitive tests. ${ }^{20}$ The magnitude of effect of retirement on cognitive functioning is lower than the estimates obtained by Rohwedder and Willis (2010). This may be due to the fact that, contrary to their specification, our model also controls for country differences and individual characteristics. Omitting those variables is likely to violate the independence assumption between the instruments and the error term. Indeed, we observe large differences in memory score across countries; even among workers in their fifties (the observed gaps before retirement cannot be explained by differences in retirement pattern across countries). ${ }^{21}$ For instance, we observe a clear North-South gradient in memory score across European countries. At the same time, the eligibility age for retirement benefits tends to be higher in Northern countries than in Southern countries. We thus argue that the larger impact they find is mainly due to the omission of country dummies that leads to overestimate the parameter of interest.

\section{Conclusion}

This paper has analyzed the effects of retirement on cognitive functioning, measured by a test of word learning and recall, using longitudinal data on older Americans from 1998 to 2006 (HRS) and a cross-national survey on older individuals from 14 European countries (SHARE). The empirical results highlight a significant negative causal impact of retirement on cognitive functioning. This negative effect remains even when controlling for individual heterogeneity and the endogeneity of the retirement decision. We show that this relationship

${ }^{20}$ As a robustness check, we have also estimate the model that include interaction terms between country dummies and age (age age squared) and we found the same results. See Table A5 in Appendix.

${ }^{21}$ As previously mentioned, note also that HRS does not use the same list of words as SHARE. 
is unlikely to be due to reverse causality by using eligibility for Social Security and expected age of retirement as instruments for retirement. Furthermore, we find no evidence that changes in cognitive functioning affect retirement expectations. This is in accordance with results from Haardt (2008), who found no significant effect of cognitive decline on the labor force supply of older workers in England using data from the English Longitudinal Study on Ageing. The empirical analysis using the cross-national differences in age-pattern of retirement (as a result of differences in institutional settings and labor market conditions) as an instrument for retirement provides results that are in accordance with those found using the longitudinal American data. In both cases we found a significant negative, and comparable, effect of retirement on cognitive functioning, close to $10 \%$.

Those results demonstrate a causal effect of activity (here professional activity) on cognition using different large survey data and different identification strategies. Before that, arguments in favor of an effect of activities on cognition were relatively indirect coming from: (1) several experimental studies on animals (Rosenzweig and Bennett, 1972; Winocur, 1998); and (2) studies showing the presence of brain plasticity even in adults (Nudo, 1996), and that the stimulation of the environment can modulate this brain plasticity (Döbrössy and Dunnett, 2001).

On a theoretical point of view, all these results support the disuse perspective (Salthouse, 1991), which assumes that decreases in activity patterns result in atrophy of cognitive skills, while stimulating mental activities increase them (the "use-it or lose it" hypothesis), and suggest that retirement plays a significant role in explaining cognitive decline at older age. However, further studies will be necessary to specify the role of professional activities on cognition (and more particularly on the memory functioning). Indeed, a first question is to investigate whether the impact of the retirement on cognitive functioning depends on the type of professional activity: physical versus intellectual work; weak versus important workload; stressful work or not... For example, some studies have shown that intellectually demanding jobs during adulthood are associated with better cognitive functioning in later life, whereas manual labor are associated with worse cognitive functioning (Jorm et al., 1998; Potter, Helms, and Plassman, 2008). A second important question is to determine whether the relation between retirement and cognition is direct and/or whether there are some intermediate variables between retirement and cognition. Indeed, work is known to increase social interactions and a sense of self-efficacy, both 
variables being considered as important factors contributing to the maintenance of the cognitive reserve (Rowe and Kahn, 1998).

Finally, it can be underlined that memory loss and dementia among the elderly represent a major public health burden, especially in the current context of population aging. Cognitive impairments, even those not reaching the threshold of dementia diagnosis, are associated with a loss of quality of life, increased disability, and higher health-related expenditures (Albert et al., 2002; Ernst and Hay, 1997; Lyketsos et al., 2002; Tabert et al., 2002). Our findings suggest that reforms aimed at promoting labor force participation at an older age may not only insure the sustainability of social security systems but may also create positive health externalities that may in turn affect expenditures on long-term care.

The interest of future research will be to determine the long term benefit of variables like retirement on the cost of cognitive aging and dementia; cost in terms of, for example, number of days of delaying institutionalization (institutionalization being considered as the largest component of cost, accounting $84 \%$ of the costs for people with severe dementia; Hux et al., 1998).

\section{Acknowledgments}

The authors would like to thank Meltem Daysal, Andries de Grip, Thomas Dohmen, Arnaud Dupuy, Tobias Klein, Izabela Jelovac, Anne Laferrère, Pierre Pestieau, Suzann Rohwedder, Arthur Van Soest, Robert Willis, and seminar participants at Maastricht University, University of the Basque Country, Utrecht University, Tilburg University, and the participants of la Journée de Printemps de la Société de Neuropsychologie de Langue Française and the International SHARE Conference for useful comments or suggestions on earlier drafts. 


\section{References}

Adam, Stéphane, Eric Bonsang, Sophie Germain, and Sergio Perelman. 2007. "Retirement and Cognitive Reserve: a Stochastic Frontier Approach Applied to Survey Data." HEC-ULg, CREPP working papers 2007/04.

Adam, Stéphane, Martial Van der Linden, Adrian Ivanoiu, Anne-Claude Juillerat, Sophie Béchet, and Eric Salmon. 2007. "Optimization of encoding specificity for the diagnosis of early AD: The RI-48 task." Journal of Clinical and Experimental Neuropsychology, 29: 477-487.

Albert, Steven M., Sherry Glied, Howard Andrews, Yaakov Stern, and Richard Mayeux. 2002. "Primary Care Expenditures Before the Onset of Alzheimer's Disease." Neurology, 59: 573-578.

Anderson, Nicole D., and Fregus I. M. Craik. 2000. "Memory in the Aging Brain." In The Oxford Handbook of Memory, ed. E. Tulving and F. I. M. Craik, 411-425. Oxford: Oxford University Press.

Benítez-Silva, Hugo, and Debra S. Dwyer. 2005. "The Rationality of Retirement Expectations and the Role of New Information." Review of Economics and Statistics, 87: $587-592$.

Berkman, Lisa F., Teresa E. Seeman, Marilyn Albert, Dan Blazer, Robert Kahn, Richard Mohs, Caleb Finch, Edward Schneider, Carl Cotman, and Gerard McClearns. 1993. "High, Usual and Impaired Functioning in Community-Dwelling Older Men and Women: Findings from the MacArthur Foundation Research Network on Successful Aging.” Journal of Clinical Epidemiology, 46: 1129-1140.

Bernheim, B. Douglas. 1989. "The Timing of Retirement: A Comparison of Expectations and Realizations." In The Economics of Aging, ed. David A. Wise. Chicago: Chicago University Press for National Bureau of Economic Research. 
Börsch-Supan, Axel and Hendrik Jürges (Eds.). 2005. The Survey of Health, Ageing and Retirement in Europe-Methodology. Mannheim: MEA.

Bound, John, and Timothy Waidmann. 2007. "Estimating the Health Effects of Retirement." University of Michigan Retirement Research Center Working Paper, wp168.

Bound, John, David A. Jaeger, and Regina M. Baker. 1995. "Problems with Instrumental Variables Estimation When the Correlation Between the Instruments and the Endogenous Explanatory Variables is Weak." Journal of the American Statistical Association, 90 (430): 443-450.

Burtless, Gary, and Robert Moffitt. 1984. "The Effect of Social Security Benefits on the Labor Supply of the Aged." In Retirement and Economic Behavior, ed. H. Aaron and G. Burtless, 135-175. Washington: Brookings Institution.

Capurso, Antonio, Francesco Panza, Vincenzo Solfrizzi, Cristiano Capurso, Franco Mastroianni, and Angelo Del Parigi. 2000. “Age-related Cognitive Decline: Evaluation and Prevention Strategy." Recenti Progressi in Medicina, 91: 127-134.

Charles, Kerwin K. 2002. "Is Retirement Depressing? Labor Force Inactivity and Psychological Well-Being in Later Life.” NBER Working Paper No. 9033.

Coe, Norma B., and Gema Zamarro. 2008. "Retirement Effects on Health in Europe." Rand WP-588.

Coile, Courtney, and Jonathan Gruber. 2000. "Social Security Incentives for Retirement.” NBER Working Paper No. 7651.

Dave Dhaval, Inas Rashad, and Jasmina Spasojevic. 2008. "The Effects of Retirement on Physical and Mental Health Outcomes.” Southern Economic Journal, 75(2): 497-523.

Disney, Richard, and Sarah Tanner. 1999. "What Can We Learn from Retirement Expectations Data?” Institute for Fiscal Studies, Working Paper no. W99/17. 
Dixon, Roger A., Lars Bäckman, and Lars-Goran Nilsson. 2004. "New Frontiers in Cognitive Aging." Oxford: Oxford University Press.

Döbrössy, Maté D., and Stephen B. Dunnett. 2001. "The influence of environment and experience on neural grafts.” Nature Reviews Neuroscience, 2: 871-879.

Dubois, Bruno, Howard Feldman, Claudia Jacova, Steven DeKosky, Pascale Barberger-Gateau, Jeffrey Cummings, André Delacourte, Douglas Galasko, Serge Gauthier, Gregory Jicha, Kenichi Meguro, John O'Brien, Florence Pasquier, Philippe Robert, Martin Rossor, Steven Salloway, Yaakov Stern, Pieter Visser, and Philip Scheltens. 2007. "Research criteria for the diagnosis of Alzheimer's disease: revising the NINCDS-ADRDA criteria." Lancet Neurology 6(8): 734-746.

Ernst, Richard L., and Joel W. Hay. 1997. "Economic Research on Alzheimer disease: a Review of the Literature." Alzheimer Disease and Associated Disorders, 11 Suppl. 6:135145.

Evans, Denis A., Laurel A. Beckett, Marilyn S. Albert, Liesi E. Hebert, Paul A. Scherr, Harris H. Funkenstein, and James O. Taylor. 1993. "Level of Education and Change in Cognitive Function in a Community Population of Older Persons." Annals of Epidemiology, 3: $71-77$.

Fillit, Howard M., Robert N. Butler, Alan W. O'Connell, Marilyn S. Albert, James E. Birren, Carl W. Cotman, William T. Greenough, Paul E. Gold, Arthur F. Kramer, Lewis H. Kuller, Thomas T. Perls, Barbara G. Sahagan, and Tim Tully. 2002. “Achieving and Maintaining Cognitive Vitality with Aging." Mayo Clinic Proceedings, 77: 681-696.

Fratiglioni, Laura, Stéphanie Paillard-Borg, and Bengt Winblad. 2004. "An Active and Socially Integrated Lifestyle in Late Life Might Protect against Dementia." Lancet, 3: 343353. 
Griliches, Zvi, and Jerry A. Hausman. 1986. "Errors in Variables in Panel Data.” Journal of Econometrics, 31: 93-118.

Grossman, Michael. 1972. "On the Concept of Health Capital and the Demand for Health.” Journal of Political Economy, 80: 223-255.

Gruber, Jonathan, and David Wise. 1999. Social Security Programs and Retirement Around the World. Chicago: NBER and University of Chicago Press.

Gruber, Jonathan, and David Wise. 2004. Micro Modelling of Retirement Incentives in the World, Chicago: NBER and University of Chicago Press.

Haardt, David. 2008. "Cognitive Functioning and Labour Force Participation among Older Men and Women in England." SEDAP Research Paper No. 222.

Hux, Margaret J., Bernie J. O'Brien, Michael Iskedjian, Ron Goeree, Micheline Gagnon and Serge Gauthier. 1998. "Relation between severity of Alzheimer's disease and costs of caring." Canadian Medical Association Journal, 159(5): 457-465.

Jorm, Anthony F., Brian Rodgers, Alexander S. Henderson, Ailsa E. Korten, Patricia A. Jacomb, Helen Christensen, and Andrew Mackinnon. 1998. "Occupation Type as a Predictor of Cognitive Decline and Dementia in Old Age." Age and Ageing, 27(4: 477-483.

Katzman, Robert, Miriam Aronson, Paula Fuld, Claudia Kawas, Ted Brown, Hal Morgenstern, William Frishman, Lewis Gidez, Howard Eder, and Wee Lock Ooi. 1989. "Development of Dementing Illnesses in an 80-Year-Old Volunteer Cohort." Annals of Neurology, 25(4): 317-324.

Laezar, Edward P. 1986. "Retirement from the Labor Force." In Handbook of Labor Economics, Vol. 1, ed. Orley Ashenfelter and Richard Layard, 305-55. London: Elsevier. 
Le Carret, Nicolas, Sylviane Lafont, Luc Letenneur, Jean-François Dartigues, Willy Mayo, and Colette Fabrigoule. 2003. "The Effect of Education on Cognitive Performances and its Implication for the Constitution of the Cognitive Reserve." Developmental Neuropsychology, 23: 317-337.

Letenneur, Luc, Daniel Commenges, Jean-François Dartigues, and Pascale BarbergerGateau. 1994. 'Incidence of Dementia and Alzheimer's Disease in Elderly Community Residents of South-Western France." International Journal of Epidemiology, 23: 12561261.

Lyketsos, Constantine G., Oscar Lopez, Beverly Jones, Annette L. Fitzpatrick, John Breitner, and Steven DeKosky. 2002. "Prevalence of Neuropsychiatric Symptoms in Dementia and Mild Cognitive Impairment: Results from the Cardiovascular Health Study." Journal of American Medical Association, 288: 1475-1483.

Maguire, Eleanor A., David G. Gadian, Ingrid S. Johnsrude, Catriona D. Good, John Ashburner, Richard S.J. Frackowiak, and Christopher D. Frith. 2000. "NavigationRelated Structural Change in the Hippocampi of Taxi Drivers." Proceedings of the National Academy of Sciences of the United States of America, 97(8): 4398-4403.

Manski, Charles. 2004. "Measuring Expectations.” Econometrica, 72: 1329-1376.

Neumann, Kevin. 2008. "Quit your Job and Live Longer? The Effect of Retirement on Health.” Journal of Labor Research, 29 (2): 177-201.

Newson, Rachel S., and Eva B. Kemps. 2005. "General Lifestyle Activities as a Predictor of Current Cognition and Cognitive Change in Older Adults: A Cross-Sectional and Longitudinal Examination." Journal of Gerontology, 60B: 113-120.

Nudo, Randolph. J. 1996. "Functional plasticity in primate motor cortex: Implications for stroke rehabilitation." Paper presented at the Conference on Towards a New Science of Cognitive Rehabilitation, St. Louis, MO. 
OECD. 1999. Classifying Educational Programmes: Manual for ISCED-97 Implementation in OECD Countries. 1999 Edition. Paris.

Patel, Mehool D., Catherine Coshall, Anthony G. Rudd, and Charles D. Wolfe. 2002. “Cognitive Impairment after Stroke: Clinical Determinants and its Associations with Longterm Stroke Outcomes.” Journal of the American Geriatrics Society, 50(4): 700-706.

Petersen, Ronald C., Glenn E. Smith, Emre Kokmen, Robert J. Ivnik, and Eric G. Tangalos. 1992. "Memory function in normal aging." Neurology, 42: 396.

Potter, Guy G., Michael J. Helms, \& Brenda L. Plassman. 2008. “Associations of job demands and intelligence with cognitive performance among men in late life." Neurology, 70: $1803-1808$.

Prull, Mattheuw W., John D. E. Gabrieli, and Silvia A. Bunge. 2000. "Age-related Changes in Memory: A Cognitive Neuroscience Perspective." In Handbook of aging and cognition II, ed. Fregus I. M. Craik and Timothy A. Salthouse, 91-153. Mahwah, NJ: Lawrence Erlbaum Associates.

Rohwedder, Susann and Robert J. Willis. 2010. "Mental Retirement."Journal of Economic Perspectives, 24, 1; 1-20.

Rosenzweig, Mark R., and Edward L. Bennett. 1972. "Cerebral Changes in Rats Exposed Individually to an Enriched Environment." Journal of Comparative Physiology and Psychology, 80: 304-313.

Rowe, John W., and Robert L. Kahn. 1998. "Successful aging." New York: Pantheon Books.

Saint Clair, Patricia, Delia Bugliari, Sandi Chien, Steven Haider, Orla Hayden, Michael Hurd, Serhii Ilchuk, Gabriela Lopez, David Loughran, Constantijn Panis, Philip Pantoja, Monika Reti, and Julie Zissimopolous. 2007. RAND HRS Data 
Documentation, Version G. Labor and Population Program, RAND Center for the Study of Aging.

Salthouse, Timothy A. 1991. Theoretical Perspectives on Cognitive Aging, ed. Lawrence Erlbaum Associates: Hillsdale, New Jersey Hove and London.

Salthouse, Timothy A. 2006. "Mental Exercise and Mental Aging: Evaluating the Validity of the Use it or Lose it Hypothesis." Perspectives on Psychological Science, 1: 68-87.

Scarmeas, Nikolaos, Gilberto Levy, Ming-Xin Tang, Jennifer Manly, and Yaakov Stern. 2001. "Influence of Leisure Activity on the Incidence of Alzheimer's Disease." Neurology, 57: 2236-2242.

Scarmeas, Nikolaos, and Yaakov Stern. 2003. "Cognitive Reserve and Lifestyle." Journal of Clinical and Experimental Neuropsychology, 25: 625-633.

Schaie, Klaus W. 1994. "The Course of Adult Intellectual Development." American Psychologist, 49(4): 304-313.

Schooler, Carmi, Mesfin S. Mulatu, and Gary Oates. 1999. "The Continuing Effects of Substantively Complex Work on the Intellectual Functioning of Older Workers." Psychology and Aging, 14: 483-506.

Silver, Margery, Kathy Newell, Bradley Hyman, John Growdon, E. Tessa HedleyWhyte, and Thomas Perls. 1998. "Unraveling the Mystery of Cognitive Changes in Old Age: Correlation of Neuropsychological Evaluation with Neuropathological Findings in the Extreme Old." International Psychogeriatry, 10: 25-41.

Silver, Margery, Evguenia Jilinskaia, and Thomas Perls. 2001. "Cognitive Functional Status of Age-Confirmed Centenarians in a Population-Based Study." Journal of Gerontology, 56B: 134-140. 
Small, Scott A. 2001. "Age-related memory decline: Current concepts and future directions." Archives of Neurology, 58: 360-364.

Souchay, Céline, Michel Isingrini, and Loïc Espagnet. 2000. “Aging, Episodic Memory, Feeling-of-Knowing, and Frontal Functioning.” Neuropsychology, 14: 299-309.

Stern, Yaakov, Barry Gurland, Thomas K. Tatemichi, Ming-Xin Tang, David Wilder, and Richard Mayeux. 1994. "Influence of Education and Occupation on the Incidence of Alzheimer's Disease.” Journal of the American Medical Association, 271: 1004-1010.

Stern, Yaakov. 2002. "What is Cognitive Reserve? Theory and Research Application of the Reserve Concept." Journal of the International Neuropsychological Society, 8: 448460.

Stern, Yaakov. 2003. "The Concept of Cognitive Reserve: A Catalyst for Research." Journal of Clinical and Experimental Neuropsychology, 25: 589-593.

Tabert, Matias H., Steven M. Albert, L. Borukhova-Milov, Yesenia Camacho, Gregory Pelton, Xinhua Liu, Yaakov Stern, and Davangere P Devanand. 2002. "Functional Deficits in Patients with Mild Cognitive Impairment: Prediction of AD." Neurology, 58: 758-764.

Wilson, Robert S., Carlos F. Mendes De Leon, Lisa L. Barnes, Julie A. Schneider, Julia L. Bienias, Denis A. Evans, and David A. Bennett. 2002. "Participation in Cognitively Stimulating Activities and Risk of Incident Alzheimer Disease.” Journal of the American Medical Association, 287: 742-748.

Winocur, Gordon. 1998. "Environmental influences on cognitive decline in aged rats." Neurobiology of Aging, 19: 589-597. 
Ybarra, Oscar, Eugene Burnstein, Piotr Winkielman, Matthew C. Keller, Melvin Manis, Emily Chan, and Joel Rodriguez. 2008. "Mental Exercising Through Simple Socializing: Social Interaction Promotes General Cognitive Functioning." Personality and Social Psychology Bulletin, 34: 248-259. 


\section{Tables and Figures}

\section{Figure 1a: Distribution of memory score in US}

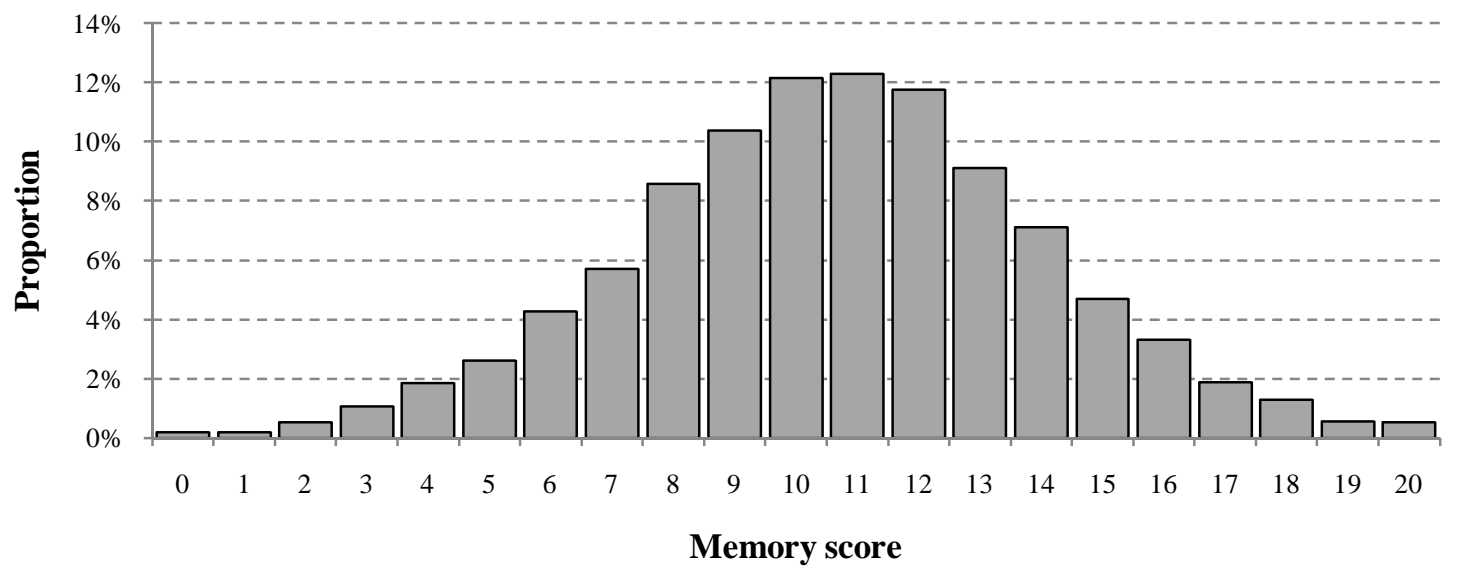

Note: Health and Retirement Study 1998-2006. All were 50-75 year-old individuals. The memory score is the sum of the number of words recalled from a list of ten words during immediate and delayed recall tasks.

\section{Figure 1b: Distribution of memory score in Europe}

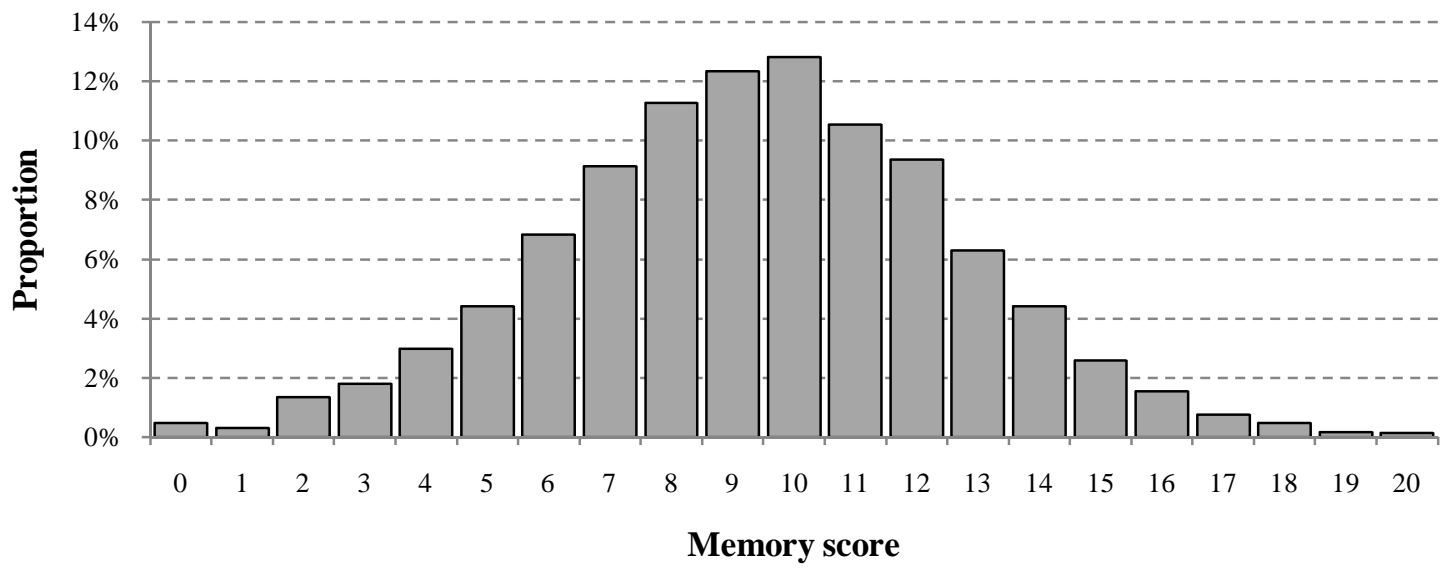

Note: The Surveey of Health, Ageing, and Retirement in Europe 2004-2006.. All were 5065 year-old individuals. The memory score is the sum of the number of words recalled from a list of ten words during immediate and delayed recall tasks. 
Figure 2: Unused labor force capacity versus tax force to retire

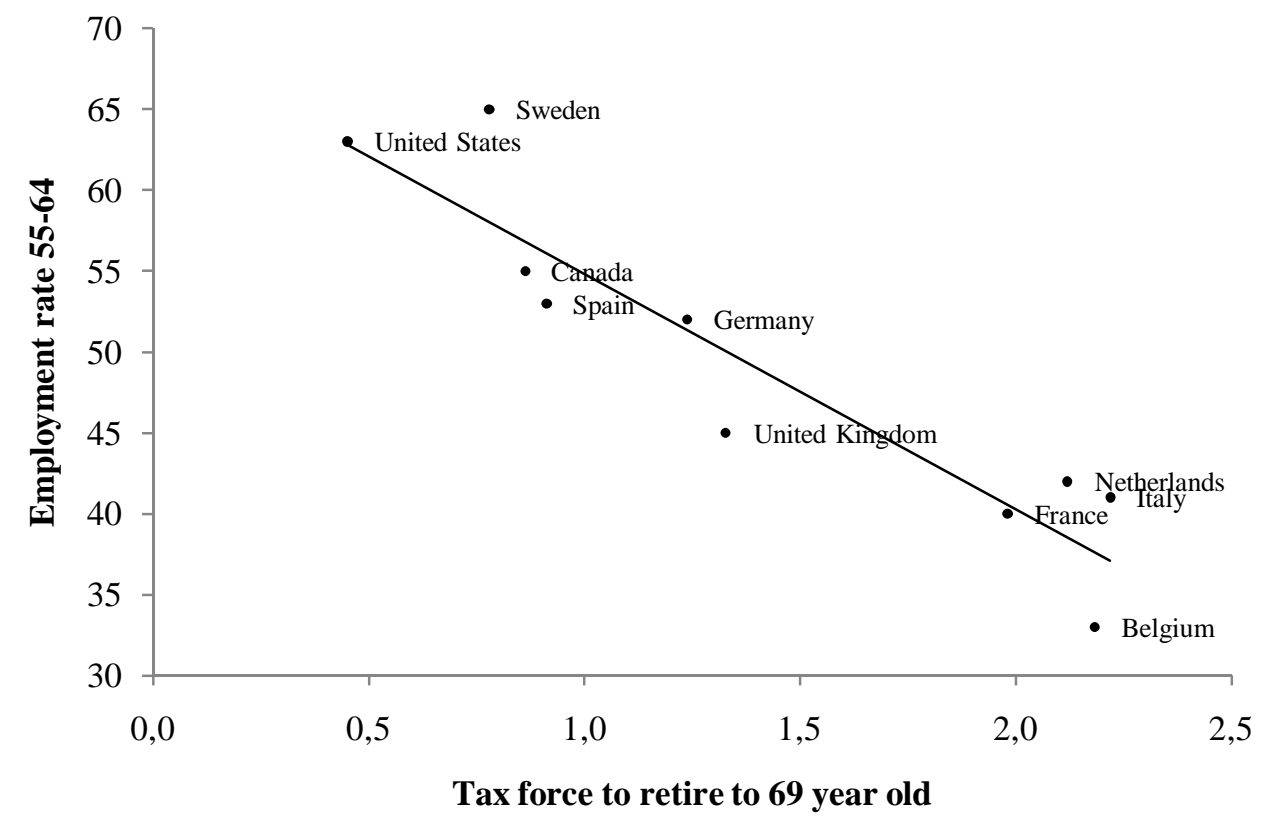

Source: Adapted from "Social Security and Retirement Around the World," Jonathan Gruber and David A. Wise, eds., Chicago: University of Chicago Press, 1999. The tax force to retire is the log of the sum of the implicit tax rates over the period from the early retirement age (when a person is first eligible for social security benefits) to age 69 .

Figure 3a: Employment rate and memory score. Relative difference between 60-65 and 50-55 year-old men

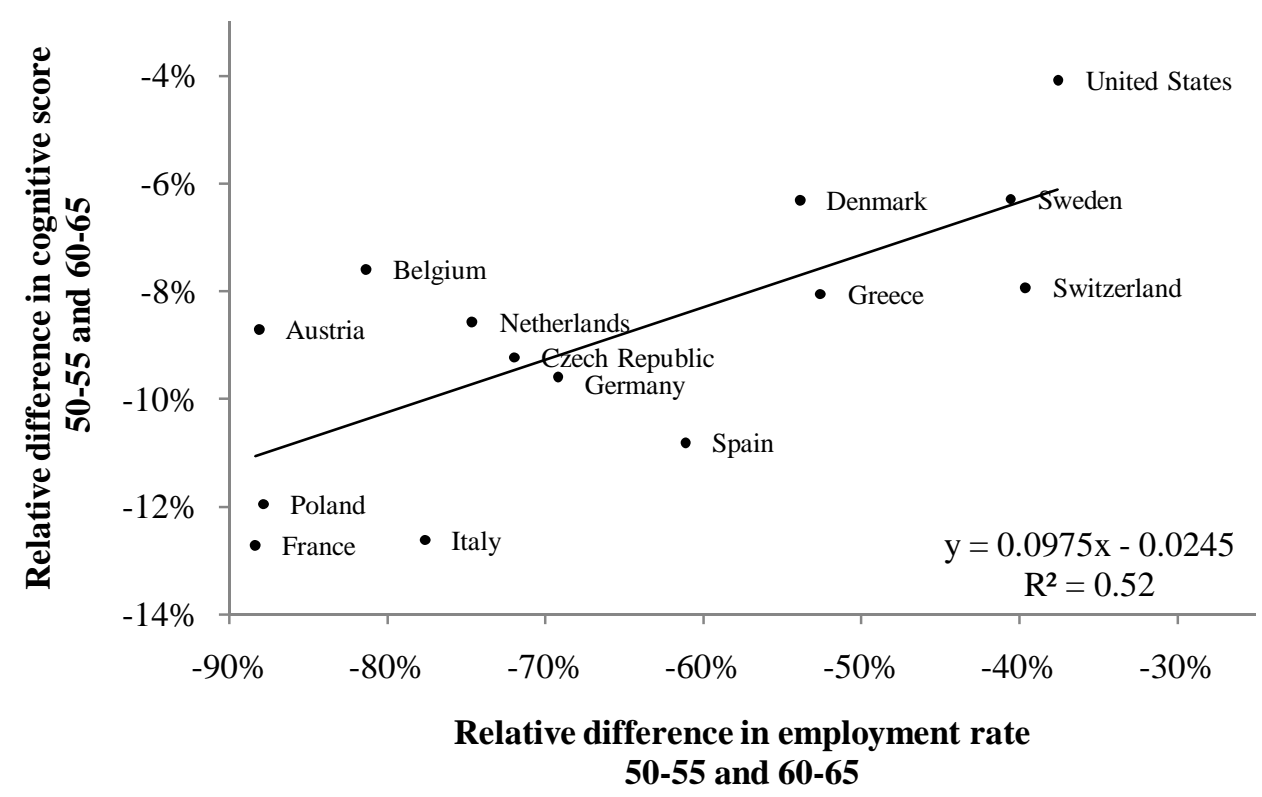

Note: Survey of Health, Ageing and Retirement in Europe 2004-2006.

Health Retirement Study 2004 for the US. The relative difference in employment rate/cognitive score is defined as $\left(\mathrm{Y}_{60-65}-\mathrm{Y}_{50-55}\right) / \mathrm{Y}_{50-55}$ for $\mathrm{Y}_{\mathrm{i}}=$ the average employment rate/cognitive score for the age category $i$. 
Figure 3b: Employment rate and fluency score. Relative difference

\section{between 60-65 and 50-55 year-old men}

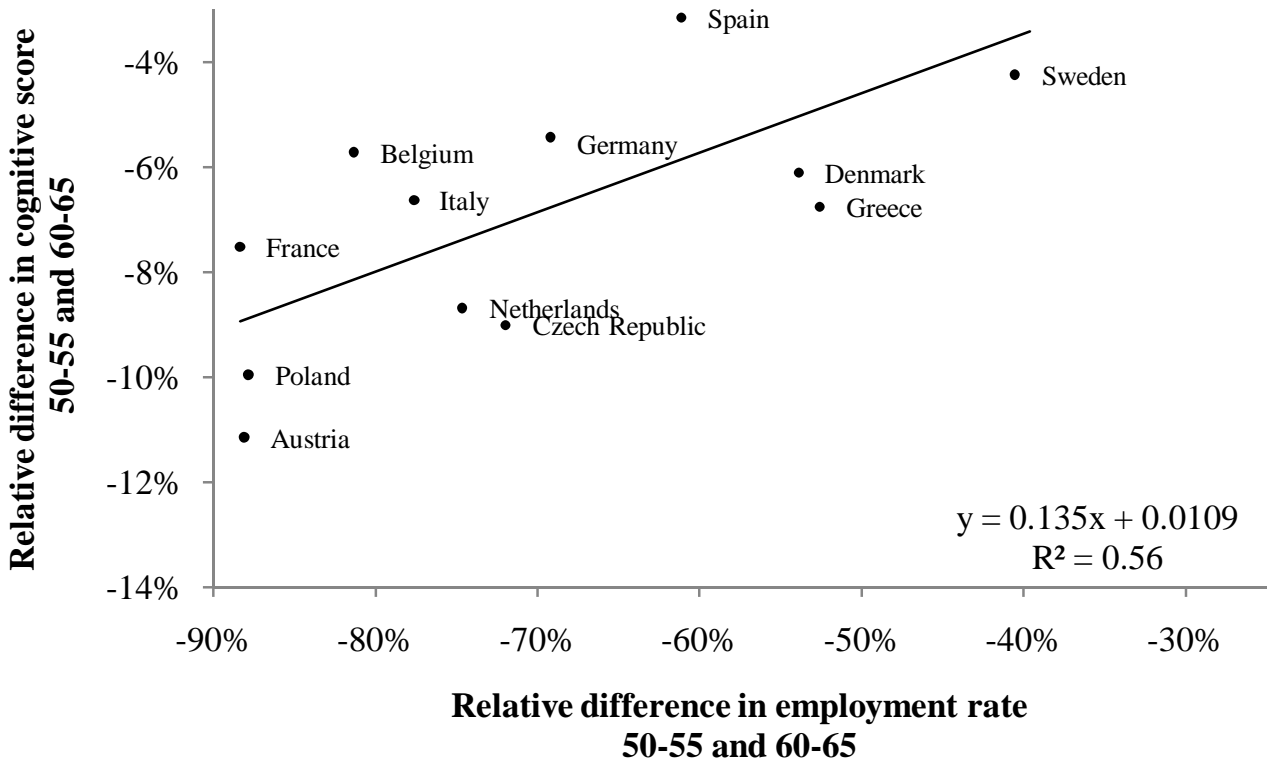

Note: Survey of Health, Ageing and Retirement in Europe 2004-2006. The relative difference in employment rate/cognitive score is defined as $\left(\mathrm{Y}_{60-65}-\mathrm{Y}_{50-55}\right) / \mathrm{Y}_{50-55}$ for $\mathrm{Y}_{\mathrm{i}}=$ the average employment rate/cognitive score for the age category $\mathrm{i}$. 
Table 1: Determinants of cognitive functioning at older age

\begin{tabular}{|c|c|c|}
\hline \multirow[t]{2}{*}{ Dependent variable: } & \multicolumn{2}{|c|}{ Memory score } \\
\hline & $\begin{array}{l}\text { OLS } \\
\text { (i) }\end{array}$ & $\begin{array}{l}\text { FE model } \\
\text { (ii) }\end{array}$ \\
\hline Constant & $-0.090 * * *$ & $-0.092 * * *$ \\
\hline & $(0.014)$ & $(0.021)$ \\
\hline \multicolumn{3}{|l|}{ Work and Retirement: } \\
\hline Working & - & - \\
\hline Retired for 0 to 4 years & $-0.119 * * *$ & $-0.039 * *$ \\
\hline Retired for 5 to 9 years & $\begin{array}{l}-0.164 * * * \\
(0.016)\end{array}$ & $\begin{array}{l}-0.047 * * \\
(0.023)\end{array}$ \\
\hline Retired for 10 years or more & $\begin{array}{l}-0.205^{* * * *} \\
(0.018)\end{array}$ & $\begin{array}{l}-0.089 * * * \\
(0.032)\end{array}$ \\
\hline Age & $\begin{array}{l}-0.032 * * * \\
(0.001)\end{array}$ & $\begin{array}{l}-0.051 * * * \\
(0.002)\end{array}$ \\
\hline$\left(\operatorname{Age}^{2}\right) / 10$ & $\begin{array}{l}-0.015^{* * * *} \\
(0.001)\end{array}$ & $\begin{array}{l}-0.012 * * * \\
(0.001)\end{array}$ \\
\hline Single household & $\begin{array}{l}-0.032 * * \\
(0.014)\end{array}$ & $\begin{array}{l}-0.008 \\
(0.019)\end{array}$ \\
\hline High blood pressure & $\begin{array}{l}-0.051 * * * \\
(0.011)\end{array}$ & $\begin{array}{l}-0.016 \\
(0.017)\end{array}$ \\
\hline Heart-related disease & $\begin{array}{l}-0.035^{* *} \\
(0.014)\end{array}$ & $\begin{array}{l}-0.043 * * \\
(0.022)\end{array}$ \\
\hline Stroke & $\begin{array}{l}-0.260 * * * \\
(0.028)\end{array}$ & $\begin{array}{l}-0.205 * * * \\
(0.040)\end{array}$ \\
\hline Years of education & $\begin{array}{l}0.101 * * * \\
(0.002)\end{array}$ & - \\
\hline Years of education ${ }^{2}$ & $\begin{array}{l}0.001 * * * \\
(0.000)\end{array}$ & - \\
\hline Woman & $\begin{array}{l}0.348 * * * \\
(0.011)\end{array}$ & - \\
\hline Ethnicity: & & \\
\hline Caucasian & - & - \\
\hline African American & $\begin{array}{l}-0.377 * * * \\
(0.017)\end{array}$ & - \\
\hline Other & $\begin{array}{l}-0.268^{* * *} \\
(0.028)\end{array}$ & - \\
\hline (Within-) $\mathrm{R}^{2}$ & 0.223 & 0.042 \\
\hline Number of observations & 53,596 & 53,596 \\
\hline Number of individuals & 16,878 & 16,878 \\
\hline
\end{tabular}

Note: Health and Retirement Study 1998-2006. All respondents were aged between 50 and 75 years. The dependent variable is the Z-score of the word recall test. Age and years of education are expressed in deviation from the sample mean. Robust standard errors are in parentheses. $(*),(* *),(* * *)$ mean that the coefficient estimate is significantly different from zero at the $10 \%, 5 \%, 1 \%$ levels, respectively. 
Table 2: Determinants of cognitive functioning at older age: IV-FE estimators

\begin{tabular}{|c|c|c|c|}
\hline \multirow[t]{2}{*}{ Dependent variable: } & \multirow{2}{*}{$\begin{array}{l}\text { Retired } \\
\text { LPM } \\
\text { (i) }\end{array}$} & \multicolumn{2}{|c|}{ Memory score } \\
\hline & & $\begin{array}{l}\text { FE model } \\
\text { (ii) }\end{array}$ & $\begin{array}{l}\text { IV-FE model } \\
\text { (iii) }\end{array}$ \\
\hline Constant & $\begin{array}{l}0.579 * * * \\
(0.009)\end{array}$ & $\begin{array}{l}-0.111 * * * \\
(0.018)\end{array}$ & $\begin{array}{l}0.078 \\
(0.088)\end{array}$ \\
\hline \multicolumn{4}{|l|}{ Work and Retirement: } \\
\hline Working & - & - & - \\
\hline Retired & - & $\begin{array}{l}-0.033 * * \\
(0.015)\end{array}$ & $\begin{array}{l}-0.305^{* *} \\
(0.131)\end{array}$ \\
\hline \multicolumn{4}{|l|}{ Instruments: } \\
\hline$\overline{\text { Eligibility I }(62+)}$ & $\begin{array}{l}0.088 * * * \\
(0.007)\end{array}$ & - & - \\
\hline Eligibility II (normal retirement age+) & $\begin{array}{l}0.142 * * * \\
(0.009)\end{array}$ & - & - \\
\hline Age & $\begin{array}{l}0.028 * * * \\
(0.001)\end{array}$ & $\begin{array}{l}-0.053 * * * \\
(0.002)\end{array}$ & $\begin{array}{l}-0.043 * * * \\
(0.005)\end{array}$ \\
\hline$\left(\operatorname{Age}^{2}\right) / 10$ & $\begin{array}{l}-0.002 * * * \\
(0.001)\end{array}$ & $\begin{array}{l}-0.013 * * * \\
(0.001)\end{array}$ & $\begin{array}{l}-0.013 * * * \\
(0.001)\end{array}$ \\
\hline Single household & $\begin{array}{l}-0.020 * * * \\
(0.008)\end{array}$ & $\begin{array}{l}-0.008 \\
(0.019)\end{array}$ & $\begin{array}{l}-0.014 \\
(0.019)\end{array}$ \\
\hline High blood pressure & $\begin{array}{l}0.020 * * \\
(0.008)\end{array}$ & $\begin{array}{l}-0.015 \\
(0.017)\end{array}$ & $\begin{array}{l}-0.009 \\
(0.017)\end{array}$ \\
\hline Heart-related disease & $\begin{array}{l}0.047 * * * \\
(0.010)\end{array}$ & $\begin{array}{l}-0.043 * * \\
(0.022)\end{array}$ & $\begin{array}{l}-0.031 \\
(0.022)\end{array}$ \\
\hline Stroke & $\begin{array}{l}0.110 * * * \\
(0.019) \\
\end{array}$ & $\begin{array}{l}-0.206^{* * *} \\
(0.040)\end{array}$ & $\begin{array}{l}-0.177 * * * \\
(0.042)\end{array}$ \\
\hline Within- $\mathrm{R}^{2}$ & 0.201 & 0.042 & 0.033 \\
\hline $\begin{array}{l}\text { Test of overidentifying restriction } \\
(p \text {-value) }\end{array}$ & & & 0.480 \\
\hline $\begin{array}{l}\text { Durbin-Wu-Hausman test } \\
(p \text {-value) }\end{array}$ & & & 0.028 \\
\hline Number of observations & 53,596 & 53,596 & 53,596 \\
\hline Number of individuals & 16,878 & 16,878 & 16,878 \\
\hline
\end{tabular}

Note: Health and Retirement Study 1998-2006. All respondents were aged between 50 and 75 years. The dependent variable is the Z-score of the word recall test. Robust standard errors are in parentheses. Age is expressed in deviation from the sample mean. $(*),(* *),(* * *)$ mean that the coefficient estimate is significantly different from zero at the $10 \%, 5 \%, 1 \%$ levels, respectively. 
Table 3: Determinants of cognitive functioning at older age: IV-FE estimators

\begin{tabular}{|c|c|c|}
\hline Dependent variable: & $\begin{array}{l}\text { Retired } \\
\text { LPM } \\
\text { (i) }\end{array}$ & $\begin{array}{l}\text { Memory score } \\
\text { IV-FE model } \\
\text { (ii) }\end{array}$ \\
\hline Constant & $\begin{array}{l}0.434 * * * \\
(0.013)\end{array}$ & $\begin{array}{l}0.092 \\
(0.060)\end{array}$ \\
\hline \multicolumn{3}{|l|}{ Work and Retirement: } \\
\hline Working & - & - \\
\hline Retired & - & $\begin{array}{l}-0.244 * * \\
(0.097)\end{array}$ \\
\hline \multicolumn{3}{|l|}{ Instruments: } \\
\hline Reaching the expected age of retirement & $\begin{array}{l}0.193 * * * \\
(0.010)\end{array}$ & - \\
\hline Age & $\begin{array}{l}0.058 * * * \\
(0.002)\end{array}$ & $\begin{array}{l}-0.031 * * * \\
(0.008)\end{array}$ \\
\hline$\left(\mathrm{Age}^{2}\right) / 10$ & $\begin{array}{l}0.012 * * * \\
(0.001)\end{array}$ & $\begin{array}{l}-0.007 * * * \\
(0.003)\end{array}$ \\
\hline Single household & $\begin{array}{l}-0.027 * * \\
(0.013)\end{array}$ & $\begin{array}{l}-0.057^{*} \\
(0.029)\end{array}$ \\
\hline High blood pressure & $\begin{array}{l}0.012 \\
(0.012)\end{array}$ & $\begin{array}{l}-0.017 \\
(0.026)\end{array}$ \\
\hline Heart-related disease & $\begin{array}{l}0.062 * * * \\
(0.018)\end{array}$ & $\begin{array}{l}-0.028 \\
(0.033)\end{array}$ \\
\hline Stroke & $\begin{array}{l}0.221 * * * \\
(0.035)\end{array}$ & $\begin{array}{l}-0.170^{* *} \\
(0.073) \\
\end{array}$ \\
\hline Within-R ${ }^{2}$ & 0.340 & 0.027 \\
\hline $\begin{array}{l}\begin{array}{l}\text { Durbin-Wu-Hausman test } \\
(p \text {-value) }\end{array} \\
\end{array}$ & & 0.048 \\
\hline Number of observations & 22,450 & 22,450 \\
\hline Number of individuals & 6,253 & 6,253 \\
\hline
\end{tabular}

Note: Health and Retirement Study 1998-2006. All respondents were aged between 50 and 75 years, were working during the first wave of interview and had reported their expected age of retirement. The dependent variable is the Z-score of the word recall test. Age is expressed in deviation from the sample mean. Robust standard errors are in parentheses. $(*),(* *),(* * *)$ mean that the coefficient estimate is significantly different from zero at the $10 \%, 5 \%, 1 \%$ levels, respectively. 
Table 4: Determinants of expectation about working at 65 years old.

\section{Fixed-effects linear model}

\begin{tabular}{|c|c|}
\hline Dependent variable: & $\begin{array}{c}\text { Self-reported probability } \\
\text { of working at } 65 \text { years } \\
\text { old }\end{array}$ \\
\hline & FE model \\
\hline Constant & $\begin{array}{l}0.480 * * * \\
(0.025)\end{array}$ \\
\hline Cognitive Z-score & $\begin{array}{l}0.002 \\
(0.004)\end{array}$ \\
\hline Age & $\begin{array}{l}0.023 * * * \\
(0.004)\end{array}$ \\
\hline$\left(\mathrm{Age}^{2}\right) / 10$ & $\begin{array}{l}0.006 * * * \\
(0.002)\end{array}$ \\
\hline Single household & $\begin{array}{l}0.039 * * * \\
(0.013)\end{array}$ \\
\hline High blood pressure & $\begin{array}{l}0.018 \\
(0.013)\end{array}$ \\
\hline Heart-related disease & $\begin{array}{l}-0.042 * * \\
(0.020)\end{array}$ \\
\hline Stroke & $\begin{array}{l}-0.067 \\
(0.046) \\
\end{array}$ \\
\hline Within- ${ }^{2}$ & 0.015 \\
\hline Number of observations & 17,774 \\
\hline Number of individuals & 7,372 \\
\hline
\end{tabular}

Note: Health and Retirement Study 1998-2006. All workers were aged between 50 and 64 years. Age is expressed in deviation from the sample mean. Robust standard errors are in parentheses. $(*),(* *),(* * *)$ mean that the coefficient estimate is significantly different from zero at the $10 \%, 5 \%, 1 \%$ levels, respectively. 
Table 5: Determinants of memory/fluency score at older age. IV estimator

\begin{tabular}{|c|c|c|c|c|c|}
\hline \multirow{3}{*}{ Constant } & \multirow{3}{*}{$\begin{array}{l}\text { Retired } \\
\text { LPM } \\
(\mathrm{i}) \\
1.003 * * * \\
(0.014)\end{array}$} & \multicolumn{2}{|c|}{ Memory score } & \multicolumn{2}{|c|}{ Fluency score } \\
\hline & & $\begin{array}{r}\text { OLS } \\
\text { (ii) }\end{array}$ & $\begin{array}{l}\text { IV } \\
\text { (iii) }\end{array}$ & $\begin{array}{l}\text { OLS } \\
\text { (iv) }\end{array}$ & $\begin{array}{l}\text { IV } \\
\text { (v) }\end{array}$ \\
\hline & & $\begin{array}{l}0.075 * * \\
(0.032)\end{array}$ & $\begin{array}{l}0.109 * * * \\
(0.042)\end{array}$ & $\begin{array}{l}0.408 * * * \\
(0.032)\end{array}$ & $\begin{array}{l}0.428 * * * \\
(0.042)\end{array}$ \\
\hline Work and Retirement: & & & & & \\
\hline Working & - & - & - & - & - \\
\hline Retired & - & $\begin{array}{l}-0.132 * * * \\
(0.013)\end{array}$ & $\begin{array}{l}-0.191 * * * \\
(0.050)\end{array}$ & $\begin{array}{l}-0.149 * * * \\
(0.013)\end{array}$ & $\begin{array}{l}-0.185 * * * \\
(0.049)\end{array}$ \\
\hline Instrument: & & & & & \\
\hline $\begin{array}{l}\text { Country/gender-specific } \\
\text { employment rate by age }\end{array}$ & $\begin{array}{l}-0.994 * * * \\
(0.023)\end{array}$ & - & - & - & - \\
\hline Age & $\begin{array}{l}-0.002 * \\
(0.001)\end{array}$ & $\begin{array}{l}-0.012 * * * \\
(0.001)\end{array}$ & $\begin{array}{l}-0.010 * * * \\
(0.003)\end{array}$ & $\begin{array}{l}-0.004 * * * \\
(0.001)\end{array}$ & $\begin{array}{l}-0.003 \\
(0.003)\end{array}$ \\
\hline$\left(\operatorname{Age}^{2}\right) / 10$ & $\begin{array}{l}-0.001 \\
(0.001)\end{array}$ & $\begin{array}{l}0.004 \\
(0.003)\end{array}$ & $\begin{array}{l}0.005 \\
(0.003)\end{array}$ & $\begin{array}{l}0.005^{*} \\
(0.003)\end{array}$ & $\begin{array}{l}0.006 * * \\
(0.003)\end{array}$ \\
\hline Single household & $\begin{array}{l}0.012 \\
(0.008)\end{array}$ & $\begin{array}{l}-0.107 * * * \\
(0.016)\end{array}$ & $\begin{array}{l}-0.107 * * * \\
(0.016)\end{array}$ & $\begin{array}{l}-0.069 * * * \\
(0.016)\end{array}$ & $\begin{array}{l}-0.069 * * * \\
(0.016)\end{array}$ \\
\hline High blood pressure & $\begin{array}{l}0.017 * * * \\
(0.006)\end{array}$ & $\begin{array}{l}-0.030 * * \\
(0.012)\end{array}$ & $\begin{array}{l}-0.029 * * \\
(0.012)\end{array}$ & $\begin{array}{l}-0.026^{* *} \\
(0.012)\end{array}$ & $\begin{array}{l}-0.025 * * \\
(0.012)\end{array}$ \\
\hline Heart-related disease & $\begin{array}{l}0.102 * * * \\
(0.009)\end{array}$ & $\begin{array}{l}-0.083 * * * \\
(0.021)\end{array}$ & $\begin{array}{l}-0.077 * * * \\
(0.022)\end{array}$ & $\begin{array}{l}-0.076 * * * \\
(0.019)\end{array}$ & $\begin{array}{l}-0.072 * * * \\
(0.020)\end{array}$ \\
\hline Stroke & $\begin{array}{l}0.176^{* * * *} \\
(0.016)\end{array}$ & $\begin{array}{l}-0.288 * * * \\
(0.041)\end{array}$ & $\begin{array}{l}-0.277 * * * \\
(0.042)\end{array}$ & $\begin{array}{l}-0.254 * * * \\
(0.037)\end{array}$ & $\begin{array}{l}-0.248 * * * \\
(0.038)\end{array}$ \\
\hline Years of education & $\begin{array}{l}-0.018 * * * \\
(0.001)\end{array}$ & $\begin{array}{l}0.065 * * * \\
(0.002)\end{array}$ & $\begin{array}{l}0.064 * * * \\
(0.002)\end{array}$ & $\begin{array}{l}0.063 * * * \\
(0.001)\end{array}$ & $\begin{array}{l}0.062 * * * \\
(0.002)\end{array}$ \\
\hline Years of education $^{2}$ & $\begin{array}{l}-0.006 * * * \\
(0.001)\end{array}$ & $\begin{array}{l}-0.008 * * * \\
(0.003)\end{array}$ & $\begin{array}{l}-0.008 * * * \\
(0.003)\end{array}$ & $\begin{array}{l}-0.010 * * * \\
(0.002)\end{array}$ & $\begin{array}{l}-0.011 * * * \\
(0.002)\end{array}$ \\
\hline Woman & $\begin{array}{l}-0.009 \\
(0.006)\end{array}$ & $\begin{array}{l}0.285^{* * * *} \\
(0.011)\end{array}$ & $\begin{array}{l}0.295^{* * * *} \\
(0.014)\end{array}$ & $\begin{array}{l}0.047 * * * \\
(0.011)\end{array}$ & $\begin{array}{l}0.053 * * * \\
(0.014)\end{array}$ \\
\hline Second time interview & $\begin{array}{l}-0.019 * * * \\
(0.004)\end{array}$ & $\begin{array}{l}0.137 * * * \\
(0.010)\end{array}$ & $\begin{array}{l}0.135^{* * * *} \\
(0.010)\end{array}$ & $\begin{array}{l}0.063 * * * \\
(0.010)\end{array}$ & $\begin{array}{l}0.062 * * * \\
(0.010)\end{array}$ \\
\hline Country fixed effects & Yes & Yes & Yes & Yes & Yes \\
\hline $\begin{array}{l}\text { Durbin-Wu-Hausman test } \\
\text { ( } p \text {-value) }\end{array}$ & & & 0.210 & & 0.358 \\
\hline $\mathrm{R}^{2}$ & 0.359 & 0.192 & 0.191 & 0.258 & 0.258 \\
\hline Number of observations & 32,641 & 32,641 & 32,641 & 32,641 & 32,641 \\
\hline
\end{tabular}

Note: Survey of Health, Ageing, and Retirement in Europe 2004-2006. All respondents were aged between 50 and 65 years. The dependent variables are the Zscore of the score obtained at the word recall test and the fluency test. Age and years of education are expressed in deviation from the sample mean. Robust standard errors are in parentheses. $(*),(* *),(* * *)$ mean that the coefficient estimate is significantly different from zero at the $10 \%, 5 \%, 1 \%$ levels, respectively. 
NOT FOR PUBLICATION

Appendix

Table 1A: Normal retirement age in the US

\begin{tabular}{ll}
\hline Cohorts: Birth date & Normal age of retirement \\
\hline Before $1 / 2 / 1938$ & 65 \\
$1 / 2 / 1938-1 / 1 / 1939$ & 65 and 2 months \\
$1 / 2 / 1939-1 / 1 / 1940$ & 65 and 4 months \\
$1 / 2 / 1940-1 / 1 / 1941$ & 65 and 6 months \\
$1 / 2 / 1941-1 / 1 / 1942$ & 65 and 8 months \\
$1 / 2 / 1942-1 / 1 / 1943$ & 65 and 10 months \\
$1 / 2 / 1943-1 / 1 / 1955$ & 66 \\
$1 / 2 / 1955-1 / 1 / 1956$ & 66 and 2 months \\
$1 / 2 / 1956-1 / 1 / 1957$ & 66 and 4 months \\
$1 / 2 / 1957-1 / 1 / 1958$ & 66 and 6 months \\
$1 / 2 / 1958-1 / 1 / 1959$ & 66 and 8 months \\
$1 / 2 / 1959-1 / 1 / 1960$ & 66 and 10 months \\
$1 / 2 / 1960$ and later & 67 \\
\hline
\end{tabular}


Table 2A: Determinants of cognitive functioning at older age: IV estimator

\begin{tabular}{|c|c|c|c|}
\hline \multirow[t]{2}{*}{ Dependent variable: } & \multirow{2}{*}{$\begin{array}{c}\text { Retired } \\
\text { LPM } \\
\text { (i) }\end{array}$} & \multicolumn{2}{|c|}{ Memory score } \\
\hline & & $\begin{array}{c}\text { OLS } \\
\text { (ii) }\end{array}$ & $\begin{array}{l}\text { IV } \\
\text { (iii) }\end{array}$ \\
\hline Constant & $\begin{array}{l}0.439 * * * \\
(0.010)\end{array}$ & $\begin{array}{l}-0.092 * * * \\
(0.014)\end{array}$ & $\begin{array}{l}-0.054 \\
(0.068)\end{array}$ \\
\hline \multicolumn{4}{|l|}{ Work and Retirement: } \\
\hline Working & - & - & - \\
\hline Retired & - & $\begin{array}{l}-0.155^{* * * *} \\
(0.012)\end{array}$ & $\begin{array}{l}-0.221 * \\
(0.117)\end{array}$ \\
\hline \multicolumn{4}{|l|}{ Instruments: } \\
\hline$\overline{\text { Eligibility I }(62+)}$ & $\begin{array}{l}0.101 * * * \\
(0.008)\end{array}$ & - & - \\
\hline Eligibility II (normal retirement age+) & $\begin{array}{l}0.172 * * * \\
(0.011)\end{array}$ & - & - \\
\hline Age & $\begin{array}{l}0.021 * * * \\
(0.001)\end{array}$ & $\begin{array}{l}-0.034 * * * \\
(0.001)\end{array}$ & $\begin{array}{l}-0.032 * * * \\
(0.004)\end{array}$ \\
\hline$\left(\operatorname{Age}^{2}\right) / 10$ & $\begin{array}{l}-0.000 \\
(0.001)\end{array}$ & $\begin{array}{l}-0.016 * * * \\
(0.001)\end{array}$ & $\begin{array}{l}-0.016 * * * \\
(0.001)\end{array}$ \\
\hline Single household & $\begin{array}{l}-0.017 * * \\
(0.008)\end{array}$ & $\begin{array}{l}-0.032 * * \\
(0.014)\end{array}$ & $\begin{array}{l}-0.033 * * \\
(0.014)\end{array}$ \\
\hline High blood pressure & $\begin{array}{l}0.045 * * * \\
(0.006)\end{array}$ & $\begin{array}{l}-0.052 * * * \\
(0.011)\end{array}$ & $\begin{array}{l}-0.049 * * * \\
(0.012)\end{array}$ \\
\hline Heart-related disease & $\begin{array}{l}0.095 * * * \\
(0.008)\end{array}$ & $\begin{array}{l}-0.037 * * \\
(0.014)\end{array}$ & $\begin{array}{l}-0.030 * \\
(0.018)\end{array}$ \\
\hline Stroke & $\begin{array}{l}0.170 * * * \\
(0.013)\end{array}$ & $\begin{array}{l}-0.262 * * * \\
(0.028)\end{array}$ & $\begin{array}{l}-0.251 * * * \\
(0.034)\end{array}$ \\
\hline Years of education & $\begin{array}{l}-0.021 * * * \\
(0.001)\end{array}$ & $\begin{array}{l}0.101 * * * \\
(0.002)\end{array}$ & $\begin{array}{l}0.100 * * * \\
(0.003)\end{array}$ \\
\hline Years of education $^{2}$ & $\begin{array}{l}-0.001 * * * \\
(0.000)\end{array}$ & $\begin{array}{l}0.001 * * * \\
(0.000)\end{array}$ & $\begin{array}{l}0.001 * * * \\
(0.000)\end{array}$ \\
\hline Woman & $\begin{array}{l}0.123 * * * \\
(0.007)\end{array}$ & $\begin{array}{l}0.342 * * * \\
(0.011)\end{array}$ & $\begin{array}{l}0.351 * * * \\
(0.019)\end{array}$ \\
\hline Ethnicity: & & & \\
\hline$\overline{\text { Caucasian }}$ & - & - & - \\
\hline African American & $\begin{array}{l}0.001 \\
(0.009)\end{array}$ & $\begin{array}{l}-0.375^{* * * *} \\
(0.017)\end{array}$ & $\begin{array}{l}-0.375^{* * *} \\
(0.017)\end{array}$ \\
\hline Other & $\begin{array}{l}0.011 \\
(0.015)\end{array}$ & $\begin{array}{l}-0.268 * * * \\
(0.028)\end{array}$ & $\begin{array}{l}-0.267 * * * \\
(0.028)\end{array}$ \\
\hline $\mathrm{R}^{2}$ & 0.272 & 0.222 & 0.222 \\
\hline Test of overidentifying restriction ( $p$-value) & & & 0.792 \\
\hline Durbin-Wu-Hausman test ( $p$-value) & & & 0.556 \\
\hline Number of observations & 53,596 & 53,596 & 53,596 \\
\hline Number of individuals & 16,878 & 16,878 & 16,878 \\
\hline
\end{tabular}

Note: Health and Retirement Study 1998-2006. All respondents were aged between 50 and 75 years. The dependent variable is the Z-score of the word recall test. Age and years of education are expressed in deviation from the sample mean. Robust standard errors are in parentheses. $(*),(* *),(* * *)$ mean that the coefficient estimate is significantly different from zero at the $10 \%, 5 \%, 1 \%$ levels, respectively. 
Table 3A: Determinants of cognitive functioning at older age: IV estimator

\begin{tabular}{|c|c|c|c|}
\hline \multirow[t]{2}{*}{ Dependent variable: } & \multirow{2}{*}{$\begin{array}{c}\text { Retired } \\
\text { LPM } \\
\text { (i) }\end{array}$} & \multicolumn{2}{|c|}{ Memory score } \\
\hline & & $\begin{array}{l}\text { OLS } \\
\text { (ii) }\end{array}$ & $\begin{array}{l}\text { IV } \\
\text { (iii) }\end{array}$ \\
\hline Constant & $\begin{array}{l}0.115 * * * \\
(0.008)\end{array}$ & $\begin{array}{l}-0.091 * * * \\
(0.021)\end{array}$ & $\begin{array}{l}-0.070 * * * \\
(0.025)\end{array}$ \\
\hline \multicolumn{4}{|l|}{ Work and Retirement: } \\
\hline$\overline{\text { Working }}$ & - & - & - \\
\hline Retired & - & $\begin{array}{l}-0.131 * * * \\
(0.019)\end{array}$ & $\begin{array}{l}-0.202 * * * \\
(0.047)\end{array}$ \\
\hline \multicolumn{4}{|l|}{ Instruments: } \\
\hline Reaching the expected age of retirement & $\begin{array}{l}0.378 * * * \\
(0.009)\end{array}$ & - & - \\
\hline Age & $\begin{array}{l}0.009 * * * \\
(0.001)\end{array}$ & $\begin{array}{l}-0.030 * * * \\
(0.003)\end{array}$ & $\begin{array}{l}-0.029 * * * \\
(0.003)\end{array}$ \\
\hline$\left(\mathrm{Age}^{2}\right) / 10$ & $\begin{array}{l}0.000 \\
(0.001)\end{array}$ & $\begin{array}{l}-0.014 * * * \\
(0.002)\end{array}$ & $\begin{array}{l}-0.014 * * * \\
(0.002)\end{array}$ \\
\hline Single household & $\begin{array}{l}0.000 \\
(0.009)\end{array}$ & $\begin{array}{l}-0.004 \\
(0.022)\end{array}$ & $\begin{array}{l}-0.004 \\
(0.022)\end{array}$ \\
\hline High blood pressure & $\begin{array}{l}0.020 * * * \\
(0.006)\end{array}$ & $\begin{array}{l}-0.044 * * * \\
(0.016)\end{array}$ & $\begin{array}{l}-0.041 * * \\
(0.016)\end{array}$ \\
\hline Heart-related disease & $\begin{array}{l}0.052 * * * \\
(0.011)\end{array}$ & $\begin{array}{l}-0.020 \\
(0.024)\end{array}$ & $\begin{array}{l}-0.015 \\
(0.024)\end{array}$ \\
\hline Stroke & $\begin{array}{l}0.151 * * * \\
(0.028)\end{array}$ & $\begin{array}{l}-0.207 * * * \\
(0.061)\end{array}$ & $\begin{array}{l}-0.195 * * * \\
(0.061)\end{array}$ \\
\hline Years of education & $\begin{array}{l}-0.008 * * * \\
(0.001)\end{array}$ & $\begin{array}{l}0.100 * * * \\
(0.003)\end{array}$ & $\begin{array}{l}0.099 * * * \\
(0.003)\end{array}$ \\
\hline Years of education $^{2}$ & $\begin{array}{l}-0.000 \\
(0.000)\end{array}$ & $\begin{array}{l}0.001 * * \\
(0.001)\end{array}$ & $\begin{array}{l}0.001 * * \\
(0.001)\end{array}$ \\
\hline Woman & $\begin{array}{l}0.035 * * * \\
(0.006)\end{array}$ & $\begin{array}{l}0.332 * * * \\
(0.017)\end{array}$ & $\begin{array}{l}0.336 * * * \\
(0.017)\end{array}$ \\
\hline Ethnicity: & & & \\
\hline Caucasian & - & - & - \\
\hline African American & $\begin{array}{l}-0.024 * * * \\
(0.009)\end{array}$ & $\begin{array}{l}-0.337 * * * \\
(0.024)\end{array}$ & $\begin{array}{l}-0.337 * * * \\
(0.024)\end{array}$ \\
\hline Other & $\begin{array}{l}-0.004 \\
(0.013)\end{array}$ & $\begin{array}{l}-0.275 * * * \\
(0.045)\end{array}$ & $\begin{array}{l}-0.276 * * * \\
(0.045)\end{array}$ \\
\hline $\mathrm{R}^{2}$ & 0.287 & 0.178 & 0.177 \\
\hline Durbin-Wu-Hausman test ( $p$-value) & & & 0.084 \\
\hline Number of observations & 22,450 & 22,450 & 22,450 \\
\hline Number of individuals & 6,253 & 6,253 & 6,253 \\
\hline
\end{tabular}

Note: Health and Retirement Study 1998-2006. All respondents were aged between 50 and 75 years, were working during the first wave of interview and had reported their expected age of retirement. The dependent variable is the Z-score of the word recall test. Age and years of education are expressed in deviation from the sample mean. Robust standard errors are in parentheses. (*), (**), (***) mean that the coefficient estimate is significantly different from zero at the $10 \%, 5 \%, 1 \%$ levels, respectively. 
Table 4A: Determinants of memory score at older age. IV estimator

Constant

$\frac{\text { LPM }}{\text { (i) }}$

$0.998 * * *$

\begin{tabular}{|c|c|}
\hline \multicolumn{2}{|c|}{ Memory score } \\
\hline OLS & IV \\
\hline (ii) & (iii) \\
\hline 0.014 & $0.069 *$ \\
\hline$(0.031$ & $(0.040)$ \\
\hline
\end{tabular}

Work and Retirement:

(0.014)

$(0.031)$

(0.040)

Working

Retired

Instrument:

Country/gender-specific

employment rate by age

$-0.993 * * *$

(0.021)

Age

$-0.003 * *$

$-0.008^{* * *}$

$-0.004 *$

$\left(\mathrm{Age}^{2}\right) / 10$

(0.001)

$(0.001)$

(0.002)

$-0.001$

$-0.001$

0.000

(0.001)

(0.003)

(0.003)

Single household

0.010

$-0.101 * * *$

$-0.100 * * *$

(0.007)

(0.014)

(0.014)

High blood pressure

$0.023 * * *$

$-0.050 * * *$

$-0.048 * * *$

$(0.005)$

(0.011)

(0.011)

Heart-related disease

$0.117 * * *$

$-0.062 * * *$

$-0.051 * * *$

(0.008)

(0.017)

(0.018)

Stroke

$0.207 * * *$

$-0.305 * * *$

$-0.285 * * *$

Years of education

$(0.014)$

(0.034)

(0.035)

$-0.007$

$0.296 * * *$

$0.311 * * *$

Years of education ${ }^{2}$

$(0.006)$

(0.010)

(0.012)

$-0.019 * * * \quad 0.069 * * * \quad 0.068 * * *$

$(0.001)$

$(0.001)$

$(0.002)$

Woman

$-0.006 * * *$

$-0.009 * * *$

$-0.010 * * *$

(0.001)

(0.002)

(0.002)

Second time interview

$-0.018 * * *$

$0.126 * * *$

$0.125 * * *$

(0.004)

(0.010)

(0.010)

\begin{tabular}{llll}
\hline Country fixed effects & Yes & Yes & Yes \\
\hline Durbin-Wu-Hausman test $(p$-value) & & & 0.033 \\
\hline $\mathrm{R}^{\mathbf{2}}$ & 0.342 & 0.212 & 0.210 \\
\hline Number of observations & 39,564 & 39,564 & 39,564
\end{tabular}

Note: Survey of Health, Ageing, and Retirement in Europe 2004-2006 and Health and Retirement Study 2004. All respondents were aged between 50 and 65 years. The dependent variables are the Z-score of the score obtained at the word recall test. Age and years of education are expressed in deviation from the sample mean. Robust standard errors are in parentheses. $(*),(* *),(* * *)$ mean that the coefficient estimate is significantly different from zero at the $10 \%, 5 \%, 1 \%$ levels, respectively. 
Table 5A: Determinants of memory/fluency score at older age. IV estimator



